\title{
Analysis of Seafloor Change around Dauphin Island, Alabama, 1987-2015
}

By James G. Flocks, Nancy T. DeWitt, and Chelsea A. Stalk

Open-File Report 2017-1112

Version 1.1, February 2018

U.S. Department of the Interior

U.S. Geological Survey 


\title{
U.S. Department of the Interior RYAN K. \\ ZINKE, Secretary
}

\author{
U.S. Geological Survey \\ William H. Werkheiser, Deputy Director \\ exercising the authority of the Director
}

\author{
U.S. Geological Survey, Reston, \\ Virginia First release: 2017 \\ Revised: February 2018 (ver. 1.1)
}

For more information on the USGS - the Federal source for science about the Earth, its natural and living resources, natural hazards, and the environment—visit https://www.usgs.gov/ or call 1-888-ASK-USGS (1-888-275-8747).

For an overview of USGS information products, including maps, imagery, and publications,

visit https://store.usgs.gov/.

\footnotetext{
Any use of trade, firm, or product names is for descriptive purposes only and does not imply endorsement by the U.S. Government.

Although this information product, for the most part, is in the public domain, it also may contain copyrighted materials as noted in the text. Permission to reproduce copyrighted items must be secured from the copyright owner.

Suggested citation:

Flocks, J.G., DeWitt, N.T., and Stalk, C.A., 2018, Analysis of seafloor change around Dauphin Island, Alabama, 1987-2015 (ver. 1.1, February 2018): U.S. Geological Survey Open-File Report 2017-1112, 19 p., https://doi.org/10.3133/ofr20171112.

ISSN 2331-1258 (online)
} 


\section{Acknowledgments}

This project is part of a collaborative effort between the U.S. Geological Survey (USGS), U.S. Army Corps of Engineers (USACE), and the State of Alabama, funded by the National Fish and Wildlife Foundation (NFWF) to investigate viable, sustainable restoration options that protect and restore the natural resources of Dauphin Island, Alabama. The authors would like to thank their collaborators at USACE-Mobile District, NFWF, State of Alabama, USGS Wetland and Aquatic Research Center, and the crew of the USACE S/N Irvington. We thank William Butler and the USACE Engineer Research and Development Center team that collected and processed the 2015 multibeam data. We would also like to thank the USGS St. Petersburg Coastal and Marine Science Center Seafloor Mapping Group (Julie Bernier, Kyle Kelso, Jake Fredericks, and Max Tuten), and Jeff Collier, Mayor of the town of Dauphin Island for their assistance. Reviews by USGS scientists Soupy Dalyander and Kathryn Smith and edits by Betsy Boynton and Marilyn Billone greatly improved this report. 


\section{Contents}

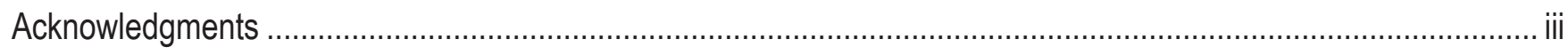

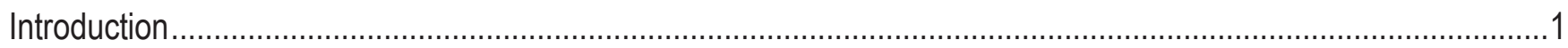

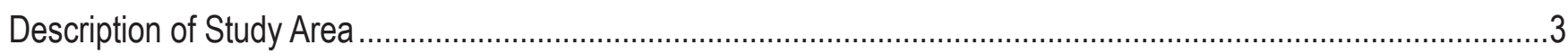

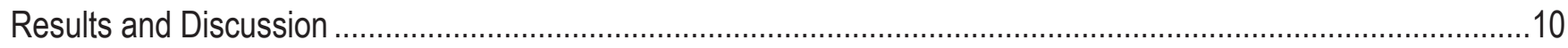

Long-Term Change (1987-2015) .......................................................................................................

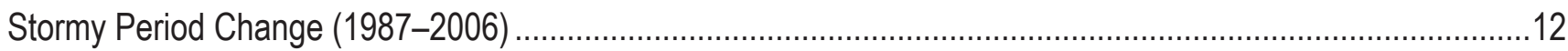

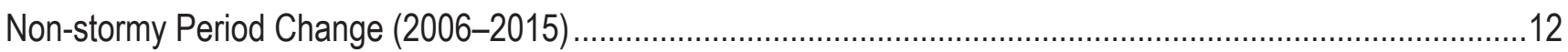

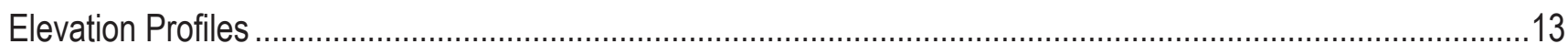

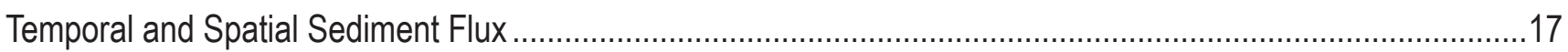

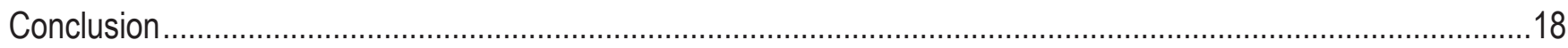

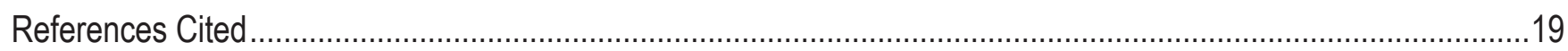

\section{Figures}

1. Maps showing the regional location of Dauphin Island, and key features discussed in this study...............1

2. Extensive shoreline erosion, overwash, breaching, and damage to the infrastructure at Dauphin Island during Hurricane Katrina in 2005.

3. Digital elevation model generated from 2015 bathymetric data

4. Trackline map showing survey extent and coverage of single beam and multibeam systems collected in July and September, 2015.

5. Trackline map showing survey extent, coverage, and survey identification from 1987-1988_....................6

6. Trackline map showing survey extent, coverage, and survey identification from 2006 .............................

7. Digital elevation model generated from the National Oceanic and Atmospheric Administration 1987-1988 bathymetric data

8. Digital elevation model generated from the National Oceanic and Atmospheric Administration 2006 bathymetric data

9. Map showing multidecadal elevation change determined by calculating the difference in digital elevation models between 1987 and 2015

10. Map showing 19-year elevation change determined by calculating the difference in digital elevation models between 1987 and 2006, referred to as the stormy period......

11. Map showing 9-year elevation change determined by calculating the difference in digital elevation models between 2006 and 2015, referred to as the non-stormy period ....

12. Elevation profiles across the Petit Bois ebb-tidal delta for the three time periods.....................................14

13. Elevation profiles from Mississippi Sound, across the island breach and into the Gulf of Mexico, for the three time periods.

14. Elevation profiles along the gulf side of Pelican Island for the three time periods ....................................15

15. Elevation profiles across the Mobile ebb-tidal delta for the three time periods .......................................... 16 
16. Elevation profiles across the gulf side of Dauphin Island for the three time periods ...............................16

17. Elevation profiles across the sound side of Dauphin Island for the three time periods ........................... 17

18. Rates of change for the two time periods and long-term for each reference subsection .........................18

\section{Tables}

1. Tropical storms passing within $185 \mathrm{~km}$ of Dauphin Island since 1987, with major impacts highlighted ........5

2. Accretion and erosion volumes, net change, and rates of change for reference subsections of morphological features/areas of submerged areas around Dauphin Island. 


\section{Conversion Factors}

International System of Units to U.S. customary units

\begin{tabular}{ccc}
\hline Multiply & By & To obtain \\
\hline & Length & \\
\hline micron $(\mathrm{um})$ & 0.001 & millimeter $(\mathrm{mm})$ \\
centimeter $(\mathrm{cm})$ & 0.394 & inch (in.) \\
meter $(\mathrm{m})$ & 3.281 & foot $(\mathrm{ft})$ \\
meter $(\mathrm{m})$ & 1.094 & yard $(\mathrm{yd})$ \\
kilometer $(\mathrm{km})$ & 0.621 & mile $(\mathrm{mi})$ \\
kilometer $(\mathrm{km})$ & 0.540 & mile, nautical (nmi) \\
\hline & Area & acre \\
\hline square kilometer $\left(\mathrm{km}^{2}\right)$ & 247.1 & \\
square kilometer $\left(\mathrm{km}^{2}\right)$ & 0.386 & cubic yard $\left(\mathrm{yd}^{3}\right)$ \\
\hline & Volume & cubic foot $\left(\mathrm{ft}^{3}\right)$ \\
\hline cubic meter $\left(\mathrm{m}^{3}\right)$ & 1.31 & \\
\hline cubic meter $\left(\mathrm{m}^{3}\right)$ & 35.31 & acre-foot per year $(\mathrm{acre}-\mathrm{ft} / \mathrm{yr})$ \\
\hline
\end{tabular}

\section{Datum}

Vertical coordinate information is referenced to the North American Vertical Datum of 1988 (NAVD 88, GEOID12A), and converted to MLLW for analysis purposes. Units of all vertical measurements are in meters.

Horizontal coordinate information is referenced in the geographic coordinates World Geodetic System of 1984 (WGS 84); however, data were projected into Universal Transverse Mercator (UTM) coordinate system for analysis purposes.

\section{Abbreviations}

$\begin{array}{ll}\text { DEM } & \text { digital elevation model } \\ \text { DGPS } & \text { Differential Global Positioning System } \\ \text { GMT } & \text { Generic Mapping Tools } \\ \text { GPS } & \text { Global Positioning System } \\ \text { Lidar } & \text { light and detection and ranging } \\ \text { MLLW } & \text { mean lower low water } \\ \text { NAVD } & \text { North American Vertical Datum } \\ \text { USGS } & \text { U.S. Geological Survey } \\ \text { UTM } & \text { Universal Transverse Mercator } \\ \text { WGS } & \text { World Geodetic System }\end{array}$




\title{
Analysis of seafloor change around Dauphin Island, Alabama, 1987-2015
}

\author{
By James G. Flocks, Nancy T. DeWitt, and Chelsea A. Stalk
}

\section{Introduction}

Dauphin Island is a 26-km-long barrier island located southwest of Mobile Bay, Alabama, in the north-central Gulf of Mexico (fig. 1). The island contains sandy beaches, dunes, maritime forests, freshwater ponds and intertidal wetlands, providing habitat for many endangered and threatened species. Dauphin Island also provides protection for and maintains estuarine conditions within Mississippi Sound, supporting oyster habitat and seagrasses. Wetland marshes along the Alabama mainland are protected by the island from wave-induced erosion during storms approaching from the Gulf of Mexico. Over the years, the island has been eroded by storms, most recently by Hurricane Ivan (2004) and Hurricane Katrina (2005) (Ivan/Katrina), which breached the island along its narrowest extent and caused damage to infrastructure (fig. 2). Along with storms producing significant episodic change, long-term beach erosion has exposed numerous pine tree stumps in the shoreface. The stumps are remnants of past maritime forests and reflect the consistent landward retreat of the island (Parker and others, 1997).

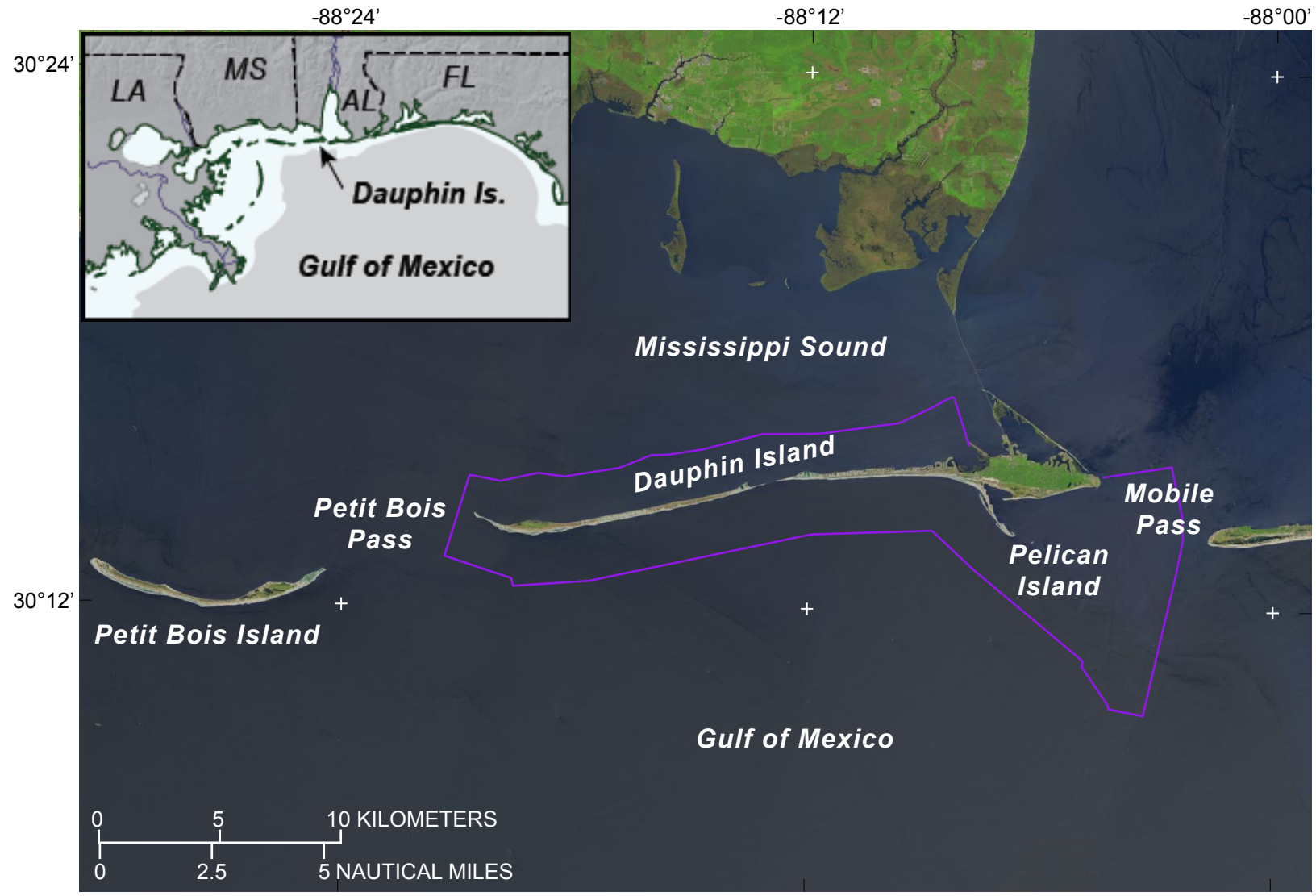

Figure 1. Maps showing the regional location of Dauphin Island (inset), and key features discussed in this study. The polygon (outlined in purple) represents the extent of the 2015 bathymetric survey. The background satellite image is from the 2014 U.S. Geological Survey Landsat 8. 


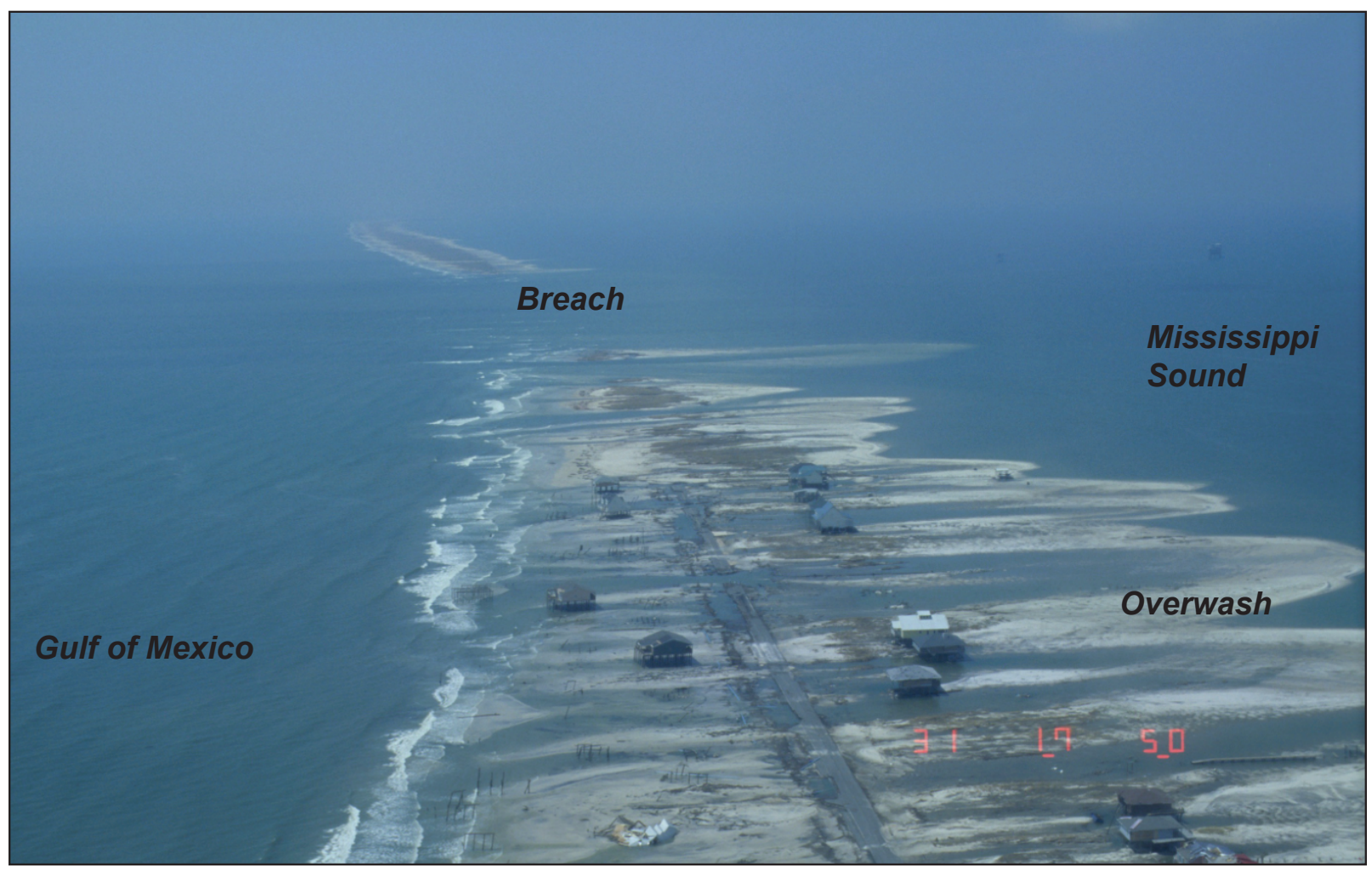

Figure 2. Extensive shoreline erosion, overwash, breaching, and damage to the infrastructure at Dauphin Island during Hurricane Katrina in 2005. The view is of the central portion of the island looking west. The image was taken August 31, 2005, U.S. Geological Survey post-storm aerial oblique photography (https://coastal.er.usgs.gov/hurricanes/katrina/post-stormphotos/obliquephotos.html).

Island change has prompted the State of Alabama to evaluate restoration alternatives to increase island resilience and sustainability by protecting and preserving the natural habitat, and by understanding the processes that influence shoreline change. Under a grant from the National Fish and Wildlife Foundation (NFWF), restoration alternatives are being developed that will allow the State to make decisions on engineering and ecological restoration designs based on scientific analysis of likely outcomes and tradeoffs between impacts to stakeholder interests. Science-based assessment of the coastal zone requires accurate and up-to-date baseline data to provide a valid image of present conditions and to support modeling of coastal processes. Bathymetric elevation measurements are essential to this requirement. In August 2015, the U.S. Army Corps of Engineers (USACE) and the U.S. Geological Survey (USGS) conducted single beam and multibeam bathymetric surveys around Dauphin Island using a variety of shallow draft vessels and equipment. More than 95 square kilometers $\left(\mathrm{km}^{2}\right)$ of seafloor was imaged. The data were integrated into a seamless digital elevation model (DEM) to provide a highresolution bathymetric map of the seafloor (fig. 3) extending $9.5 \mathrm{~km}$ seaward from the island's eastern end and approximately $2 \mathrm{~km}$ along the rest of the island on the gulf and sound sides. Water depths range from 0.3 to 15.0 meters $(\mathrm{m})$, with depths greater than $10.0 \mathrm{~m}$ constrained to the Mobile ship channel on the extreme eastern flank of the coverage.

To measure seafloor change, two periods of historic hydrographic survey data were acquired from the National Oceanic and Atmospheric Administration (NOAA) National Centers for Environmental Information data archive. The two timeframes (1987-1988 and 2005-2007) were selected for their 


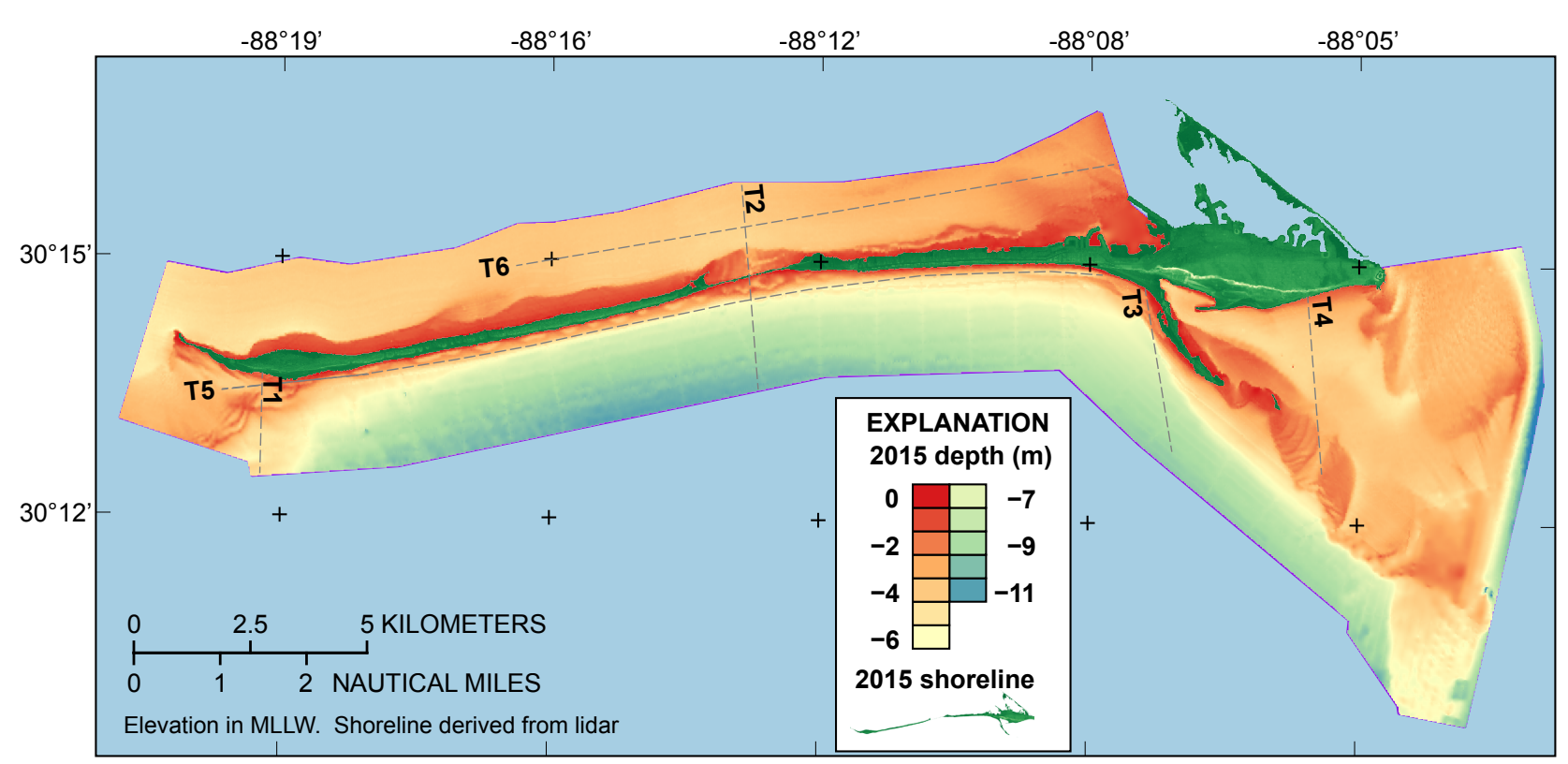

Figure 3. Digital elevation model (DEM) generated from 2015 bathymetric data. Overlain on the DEM are transect locations (T1-T6) used to represent vertical change over time.

completeness of spatial coverage and because they encompass a period of significant storm impacts to the island. These timeframes were compared to each other and with the 2015 dataset to monitor elevation gain (sediment accretion) and elevation loss (sediment erosion) over time. Sediment dynamics is by far the most significant driver of nearshore elevation change in this area. The Mississippi-Alabama inner shelf is a passive margin (Flocks and others, 2011), and other influences on elevation change (for example, tectonic adjustment, Holocene subsidence, and eustatic sea-level rise) are neither significant nor variable enough over this time period to have an imprint.

\section{Description of Study Area}

Dauphin Island is typically characterized in east and west segments based on geomorphology (fig. 3). The eastern quarter of the island is up to $2 \mathrm{~km}$ wide with elevations that exceed $8 \mathrm{~m}$. This part of the island rests on a core of hardened Pleistocene barrier ridge-deposits that became the locus of sediment deposition at the beginning of island evolution (Otvos and Giardino, 2004). In contrast, the western three quarters of the island is narrow $(<500 \mathrm{~m})$ and consists of low-elevation $(<4-\mathrm{m})$ sandy dunes that are subject to frequent overwash and breaching (fig. 2). In the submerged environment, seaward of the eastern end of the island is the highly dynamic Mobile Bay ebb-tidal delta, which extends approximately $10 \mathrm{~km}$ seaward of the island (fig. 3). On the western flank of the delta is a region of shoals and ephemeral islands that reflect the net westward transport of sand along the periphery of the ebbtidal delta shield, driven by a prevailing southeast wave approach and tidal-flow dynamics (Byrnes and others, 2008). Pelican Island (fig. 1), also referred to as Sand Island, is a shoal that has been migrating toward and appending to Dauphin Island over the past century. (It is presently appended to Dauphin Island, adjacent to transect T3 in fig. 3.) West of these features, along the length of the island, the shoreface and inner shelf are comparatively featureless, with a gentle ( 0.6 degree) seaward slope. This morphology is consistent with most of the Mississippi-Alabama inner shelf at water depths less than $20 \mathrm{~m}$ (Flocks and others, 2011). 
The western end of the island terminates at the Petit Bois Pass (fig. 1) and its ebb-tidal delta. The pass formed as a breach in the island during an unnamed hurricane in the mid-18th century (Otvos and Carter, 2013), separating Petit Bois Island from Dauphin Island (fig. 1). Since this breach, Petit Bois Island has been migrating westward, widening the pass and expanding the ebb-tidal delta deposits seaward (Flocks and others, 2015). As with the inlet at the eastern end of island, tidal dynamics control sediment transport processes within the Petit Bois Pass.

The sound side of Dauphin Island is composed of a narrow $(\sim 0.5 \mathrm{~km})$ island platform less than $2 \mathrm{~m}$ deep that slopes into Mississippi Sound (fig. 3). Water depth within the sound ranges from 2.5 to 4.5 $\mathrm{m}$. The Intracoastal Waterway Ship Channel passes through the sound just beyond the 2015 bathymetric coverage and is not included in this investigation. Flood-tide delta and storm overwash deposits are visible in the bathymetry at the aforementioned breach in the central part of the island (fig. 3). The breach occurred during Hurricane Ivan (2004) and was significantly widened by Hurricane Katrina the following year (fig. 2). In 2011 a rock structure was added to close the breach and, subsequently, longshore transport has begun to build out a beach in front of the structure.

Historical wave climate measured from a buoy approximately $54 \mathrm{~km}$ southeast of Dauphin Island (NOAA National Data Buoy Center Station 42012) indicates a predominantly southeast wave approach (Flocks and others, 2015), directing sediment transport from east to west along the island shoreface. Over the past half century, Byrnes and others (2008) estimated that approximately 4.6x104 cubic meters per year $\left(\mathrm{m}^{3} / \mathrm{yr}\right)$ of sediment was transported from the Mobile ebb-tidal delta west to Dauphin Island. Over the same time period, $2.4 \times 10^{5} \mathrm{~m}^{3} / \mathrm{yr}$ of sediment was eroded from the middle and western portion of the island (Byrnes and others, 2008). This suggests that five times the amount of sediment is eroded from the island shoreface than is delivered each year. Steady longshore sediment-transport rates and volumes are punctuated by storm impacts which rapidly erode sand from the beach and shoreface. Since 1987, 14 named storms with tropical storm strength or greater passed within $185 \mathrm{~km}$ (100 nautical miles) of Dauphin Island (table 1). Storm surges up to $3 \mathrm{~m}$ (Hurricane Ivan) caused shoreface erosion, island overwash, and breaching. Since Hurricane Katrina in 2005, only two storms have passed within $185 \mathrm{~km}$ of the islands (table 1), in general reflecting a period of low storm activity in the northern Gulf of Mexico in general.

\section{Methods}

A bathymetric survey was conducted in 2015 using a suite of acoustic systems and platforms; tracklines of coverage are shown in figure 4. In July 2015, the USGS collected single-beam bathymetry in the shallow waters around the island. For a complete description of the methodology used to collect these data see DeWitt and others (2017). Shallow draft vessels, including personal watercraft equipped with single-beam acoustic systems and Digital Global Positioning System (DGPS), were used to access these areas. Positioning was corrected using DGPS base stations installed over geodetic benchmarks located on the island. Variable sound velocity within the water column was corrected using periodic casts of portable sound-velocity profilers. Boat heave, pitch, and roll were compensated using an internal motion reference system, whereas the personal water craft used a very high GPS sampling rate ( 0.1 second) and a narrow (4 degree) transducer beam angle to compensate for motion.

In September 2015, the USACE Engineer Research and Development Center completed multibeam surveys in deeper water (up to 6-m water depth) around the Petit Bois Pass and sound-side of the island using a similar methodology (William Butler, oral comm.), while a joint USACE/USGS survey occupied the deeper waters on the gulf side of the island using the USACE survey vessel Irvington equipped with a multibeam system. These data, along with 2015 lidar elevations of the shoreline acquired by the USGS, were integrated to generate a DEM of the coastal zone (fig. 3). 
Table 1. Tropical storms passing within $185 \mathrm{~km}(100 \mathrm{~nm})$ of Dauphin Island since 1987, with major impacts highlighted. Dashed line separates the 1987-2006 and 2006-2015 time periods. Storm data extracted from the National Oceanic and Atmospheric Administration Historical Hurricane Track Tools v. 4.0 (https://coast.noaa.gov/hurricanes/).

[KM: kilometers; MB: millibars; KTS: knots; M: meters]

\begin{tabular}{llcccccc}
\hline Name & Date & $\begin{array}{c}\text { Closest } \\
\text { distance } \\
\text { KM }\end{array}$ & Category & $\begin{array}{c}\text { Central } \\
\text { pressure } \\
\text { MB }\end{array}$ & $\begin{array}{c}\text { Central } \\
\text { wind speed } \\
\text { KTS }\end{array}$ & $\begin{array}{c}\text { Wind speed } \\
\text { at Dauphin } \\
\text { KTS }\end{array}$ & $\begin{array}{c}\text { Surge at } \\
\text { Dauphin } \\
\text { M }^{*}\end{array}$ \\
\hline Ida & Nov 2009 & 8 & TS & 998 & 45 & 30 & 0.8 \\
Claudette & Aug 2009 & 166 & TS & 1005 & 40 & 23 & - \\
Katrina & Aug 2005 & 136 & H3 & 925 & 107 & 66 & 2.1 \\
Dennis & Jul 2005 & 135 & H3 & 942 & 110 & 44 & 0.9 \\
Cindy & Jul 2005 & 26 & TS & 995 & 45 & 44 & - \\
Arlene & Jun 2005 & 74 & TS & 991 & 50 & 34 & 0.8 \\
Ivan & Sep 2004 & 34 & H3 & 946 & 105 & 79 & 2.9 \\
Hanna & Sep 2002 & 35 & TS & 1003 & 50 & 36 & 1.1 \\
\hline Georges & Sep 1998 & 57 & H2 & 964 & 90 & 37 & 1.6 \\
Earl & Sep 1998 & 176 & H2 & 988 & 85 & 45 & 0.3 \\
Danny & Jul 1997 & 15 & H1 & 984 & 70 & 63 & 1.8 \\
\hline Opal & Oct 1995 & 98 & H3 & 940 & 105 & 53 & 0.8 \\
Erin & Aug 1995 & 110 & H2 & 973 & 85 & 36 & - \\
Alberto & Jul 1994 & 154 & TS & 993 & 55 & 21 & - \\
\hline
\end{tabular}

*Negligible or unknown surge marked as (-).

All of the bathymetric data was processed in the World Geodetic System (WGS84) with elevation control in the North American Vertical Datum NAVD88 (GEOID12A), and converted to Universal Transverse Mercator (UTM) zone 16 and mean lower low water (MLLW) for comparison with legacy bathymetric datasets. The merged DEM extends landward to include the shoreline, a zero-meter elevation contour extracted from a 2015 USGS topographic-lidar survey of Dauphin Island. Once the various datasets were merged, a 5-m running mean was applied across the data to avoid aliasing short wavelengths. The blockmean function in the Generic Mapping Tools (GMT, ver. 5) suite of data manipulation tools was used for this process. The resulting data file was then gridded to $50-\mathrm{m}$ grid cells using the GMT surface algorithm with a search radius of $200 \mathrm{~m}$ to initialize the grid and a tension filter of 0.03 to suppress spurious oscillations. A grid mask generated from a polygon digitized around the survey area was applied to the resulting grid to exclude areas of no data using the GMT grdmask and grdmath functions (fig. 4, extent of analysis). The root-mean-square (RMS) error for the grid relative to the soundings across acquisition platforms averaged $0.022 \mathrm{~m}$.

To monitor seafloor change over time, trackline data points from the 1987-1988 and 2005-2007 time periods were downloaded from the NOAA National Centers for Environmental Information website (https://maps.ngdc.noaa.gov/viewers/bathymetry/). Data coverages and identification numbers for these time periods are shown in figures 5 and 6 . The data were converted from WGS84 to UTM zone 16 (meters) for volume estimations. Dauphin Island shorelines for 1987 and 2006 were digitized from Landsat satellite imagery (Guy, 2015), assigned a zero elevation, and merged with the bathymetric data. As with the recent dataset, a 5-m running mean was applied to each data merge, which were then gridded using the GMT surface algorithm at the same range and grid spacing as the 2015 DEM. The resulting DEMs are shown in figures 7 and 8. The RMS error comparing the DEM to original data 


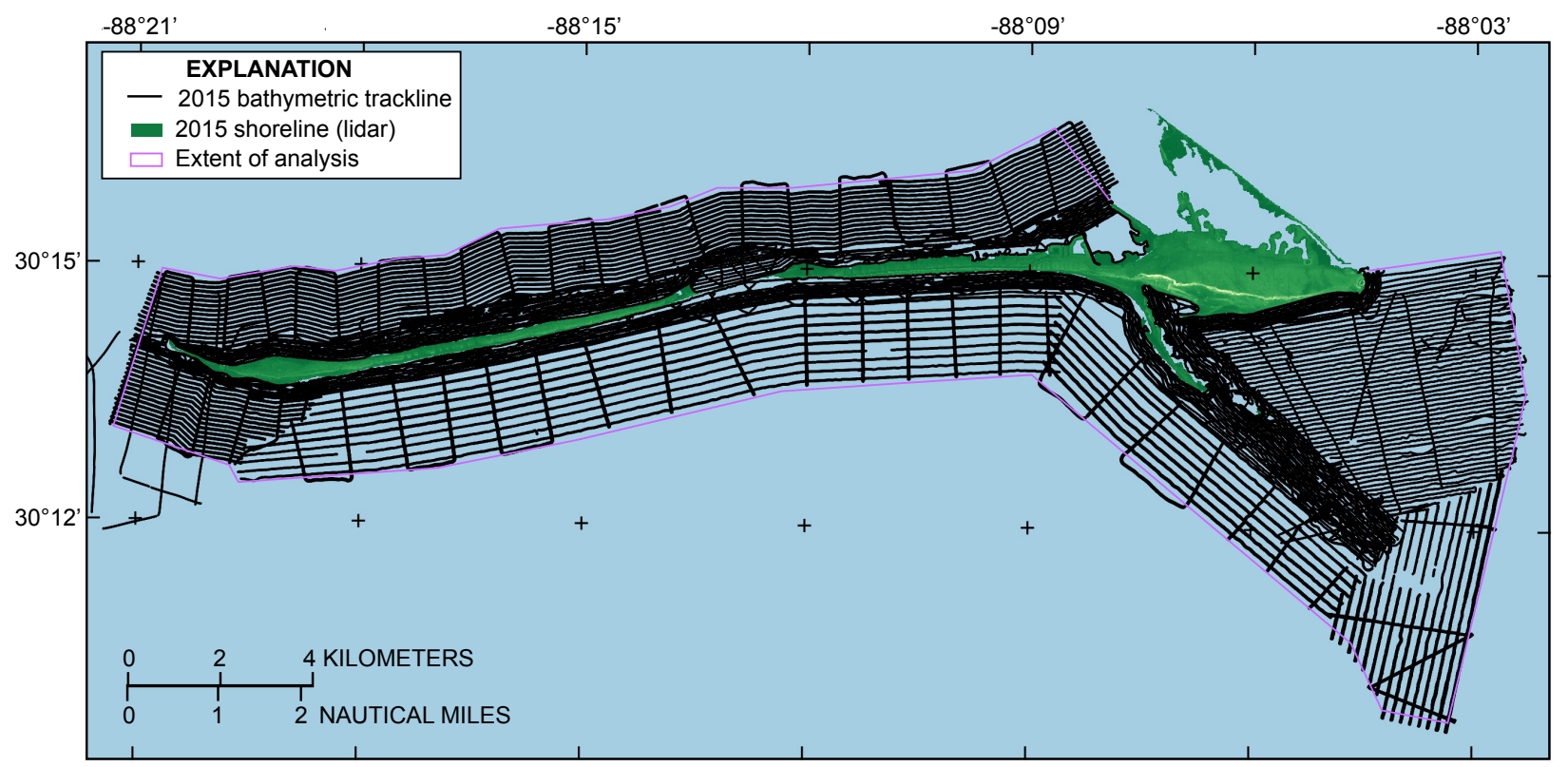

Figure 4. Trackline map showing survey extent and coverage of single beam and multibeam systems collected in July and September, 2015.

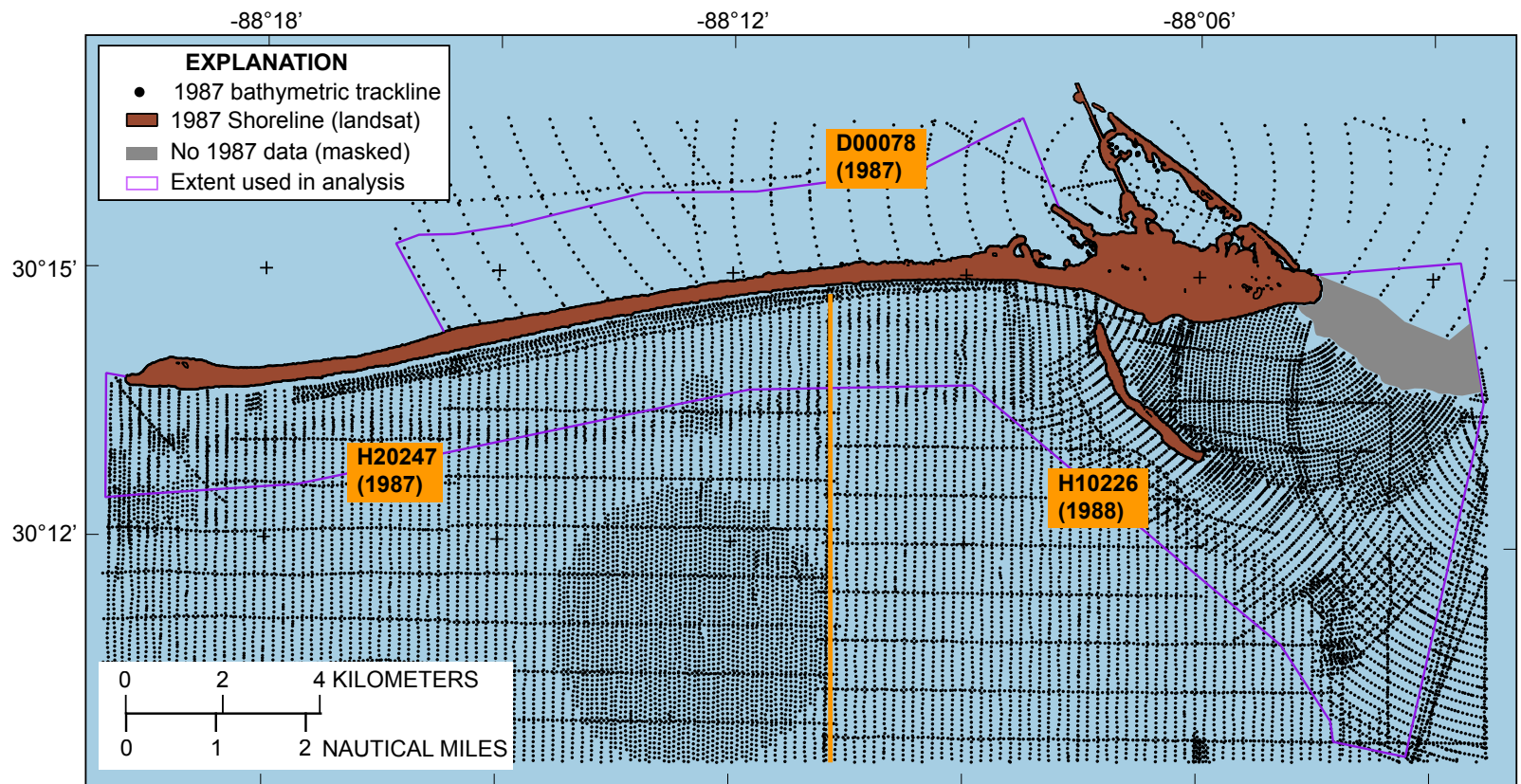

Figure 5. Trackline map showing survey extent, coverage, and survey identification from 1987-1988. National Oceanic and Atmospheric Administration hydrographic survey data (https://maps.ngdc.noaa.gov/viewers/bathymetry/).

is $0.098 \mathrm{~m}$ and $0.080 \mathrm{~m}$ for the 1987 and 2006 grids, respectively. Areas where bathymetric data were missing from the legacy datasets were masked and assigned NULL values in their respective DEMs. The DEMs were clipped to the extent of the 2015 survey, and certain areas of the legacy grids were masked because of insufficient or no data (gray background in figs. 5 and 6). Once the three DEMs were sampled to the same geographic extents and vertical datum (MLLW), the bathymetric change between each period was determined by subtracting the older period from the more recent period using the 


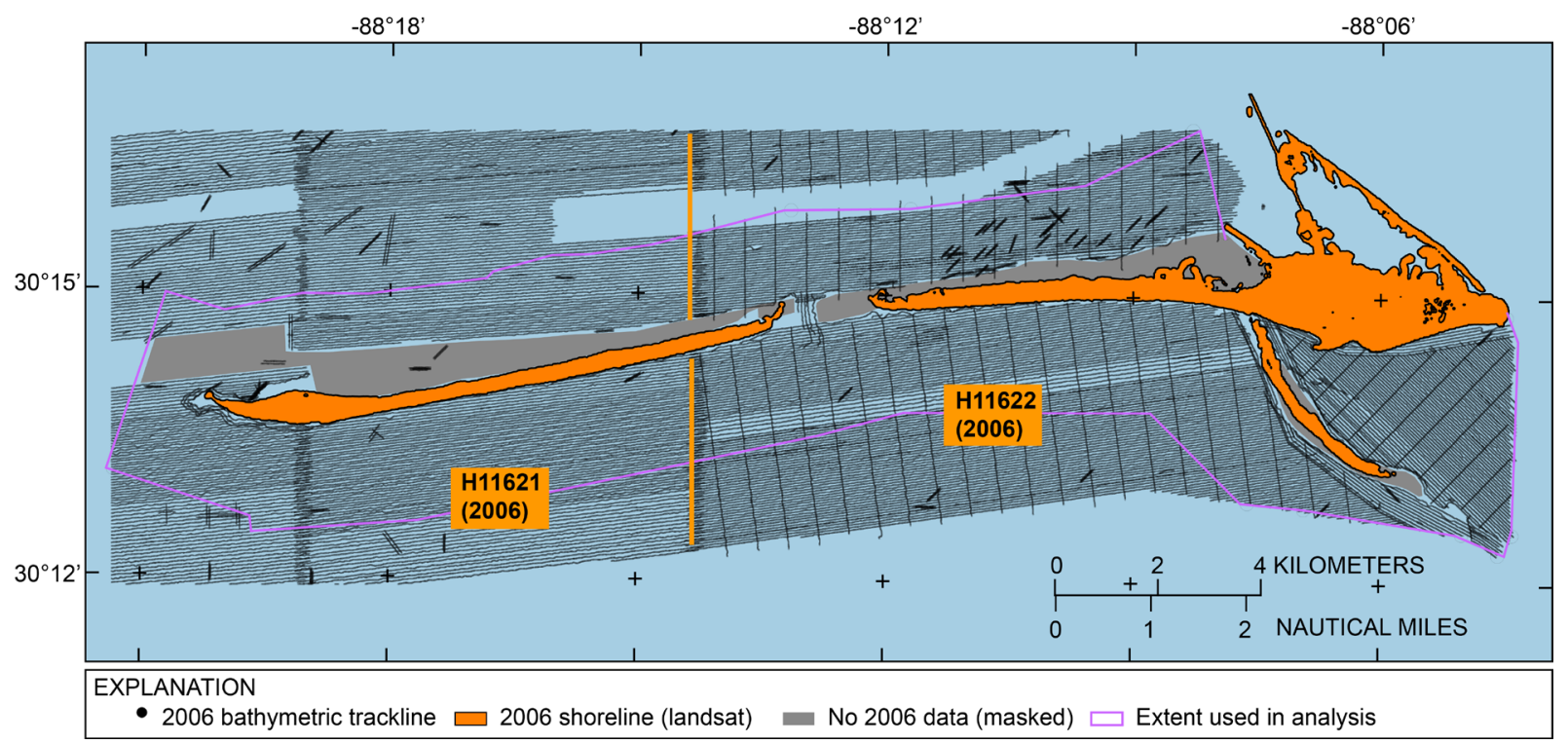

Figure 6. Trackline map showing survey extent, coverage, and survey identification from 2006. National Oceanic and Atmospheric Administration hydrographic survey data (https://maps.ngdc.noaa.gov/viewers/bathymetry/).

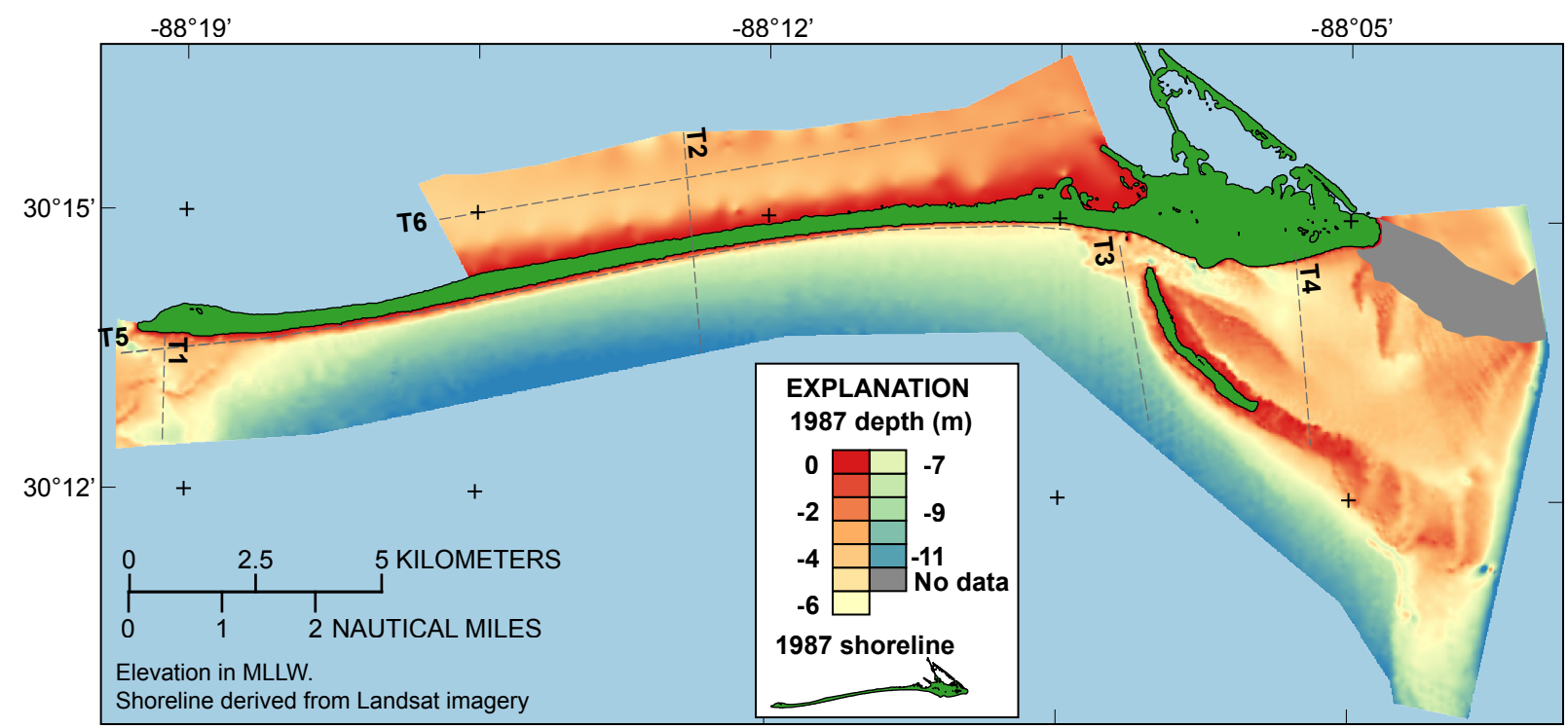

Figure 7. Digital elevation model (DEM) generated from the National Oceanic and Atmospheric Administration 1987-1988 bathymetric data. Overlain on the DEM are transect locations (T1-T6) used to represent vertical change over time.

grdmath function in GMT. This calculation provides an isopach grid of erosion (negative values) and accretion (positive values). To account for measurement uncertainty, isopach differences between $-0.25 \mathrm{~m}$ and $+0.25 \mathrm{~m}$ were considered within the error of analysis and set to zero (no change). The resulting time periods (2015-1987, 2006-1987, and 2015-2006) with erosion/accretion isopach maps are shown in figures 9-11. Bathymetric change between time periods can also be directly compared along twodimensional transects (transects T1-T6 shown in figs. 3, 7, and 8) across the DEMs with stacked results in profile to show relative elevations. These profiles were restricted to the areas of common coverage across time periods and were extracted from the DEMs using the transit plug-in included with the QGIS GIS (ver. 2.18) software. 


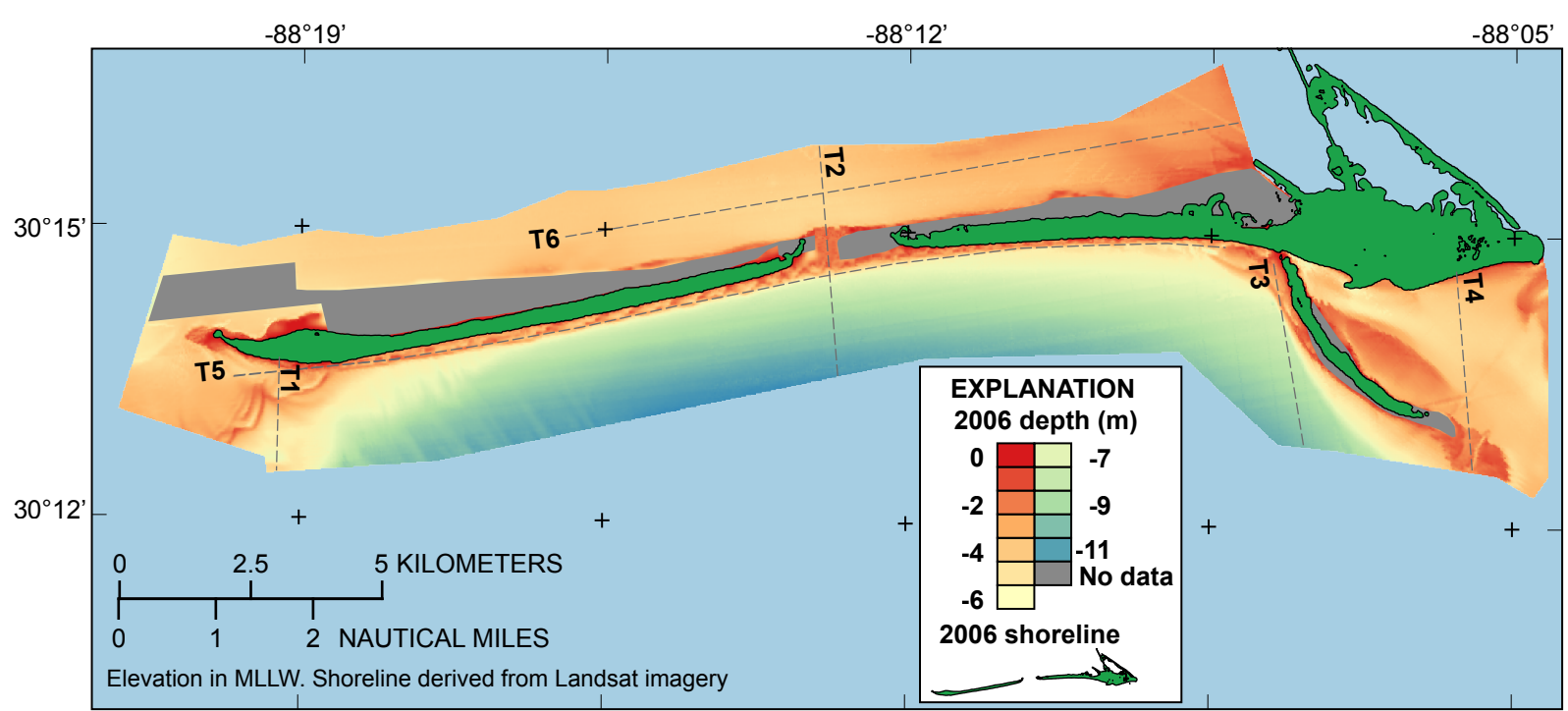

Figure 8. Digital elevation model (DEM) generated from the National Oceanic and Atmospheric Administration 2006 bathymetric data. Overlain on the DEM are transect locations (T1-T6) used to represent vertical change over time.

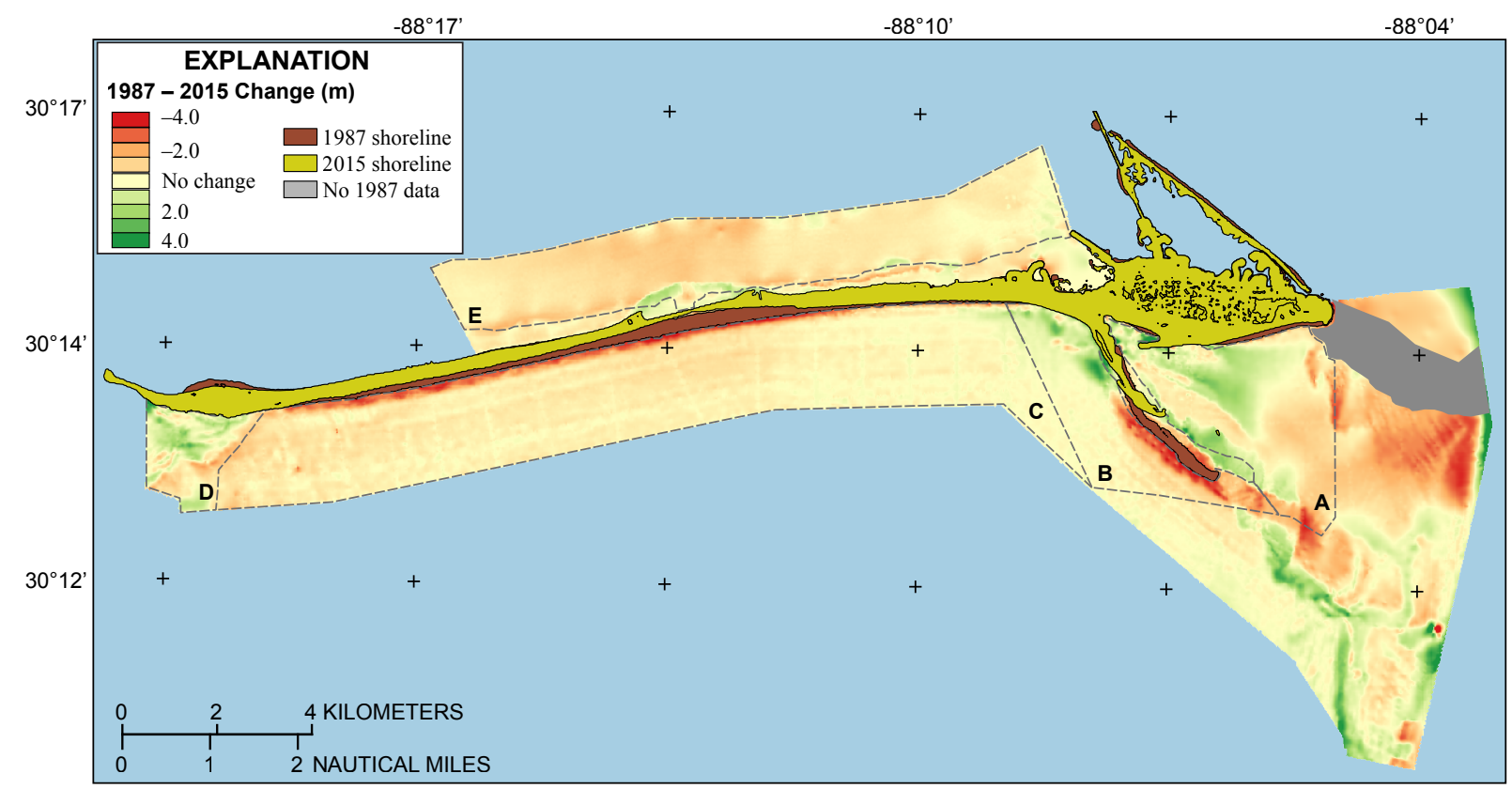

Figure 9. Map showing multidecadal elevation change determined by calculating the difference in digital elevation models (DEMs) between 1987 and 2015. The change is considered to represent accretion (positive change) and erosion (negative change) over the time period. Elevation differences within \pm 0.25 meter $(\mathrm{m})$ are considered no change. Overlain onto the DEM are polygons (labeled A-E) that represent morphological cells from which volume change statistics are calculated (table 2).

Area and volume change between the time periods was determined using the grdvolume function in GMT, which calculates area, volume, and volume per unit area for a provided polygon within a DEM. The polygons delineate areas of interest within the study area such as geomorphic features. For this analysis, the Mobile Bay ebb-tidal shoal (A), the Pelican Island shoreface (B), the Dauphin Island gulf shoreface (C), the Petit Bois Pass tidal shoal (D), and the Dauphin Island/Mississippi Sound (E) (figs. 9-11) were selected as important geomorphic features to compare for relative change around the 


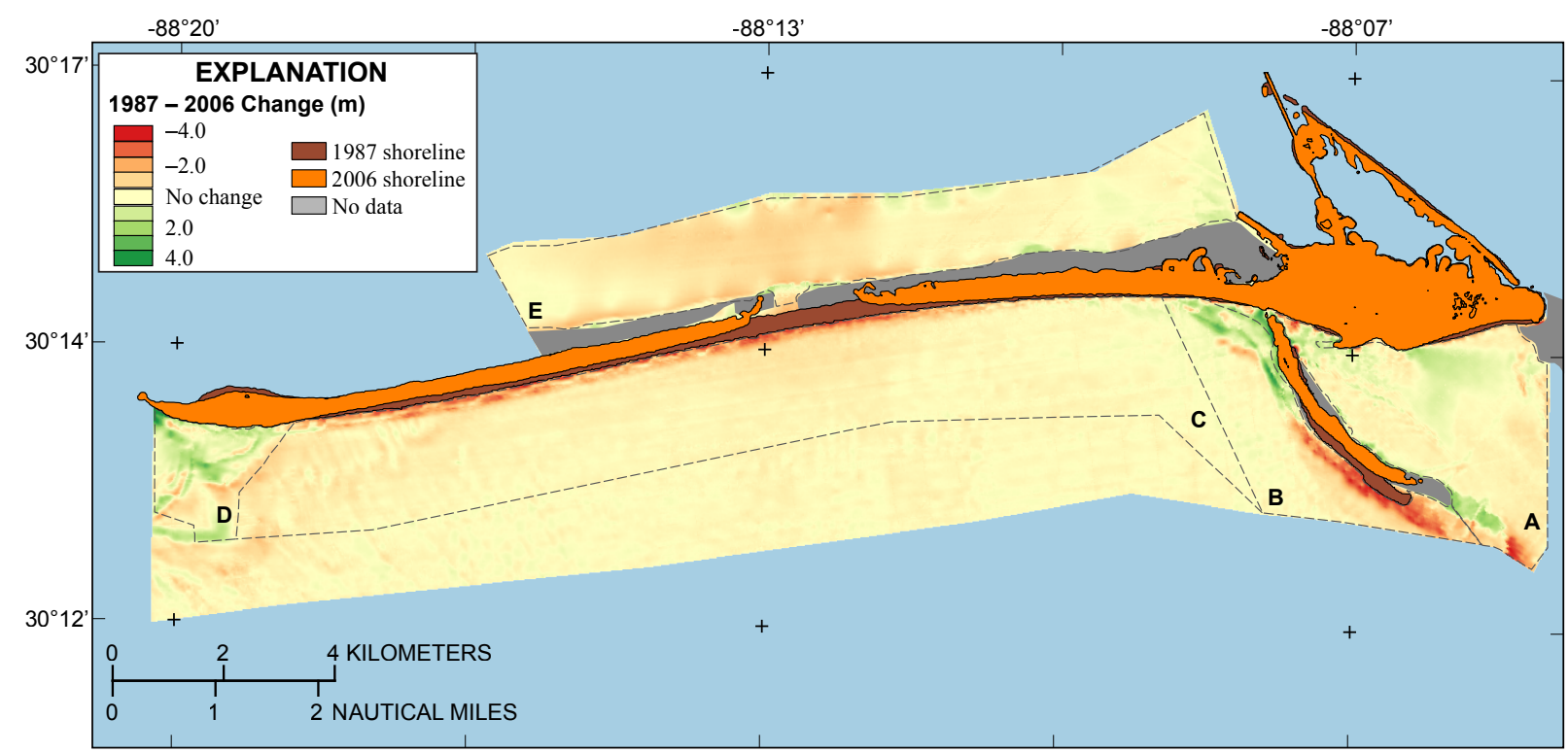

Figure 10. Map showing 19-year elevation change determined by calculating the difference in digital elevation models (DEMs) between 1987 and 2006, referred to as the stormy period. The change is considered to represent accretion (positive change) and erosion (negative change) over the time period. Elevation differences within \pm 0.25 meter $(\mathrm{m})$ are considered no change. Overlain onto the DEM are polygons (labeled A-E) that represent morphological cells from which volume change statistics are calculated (table 2).

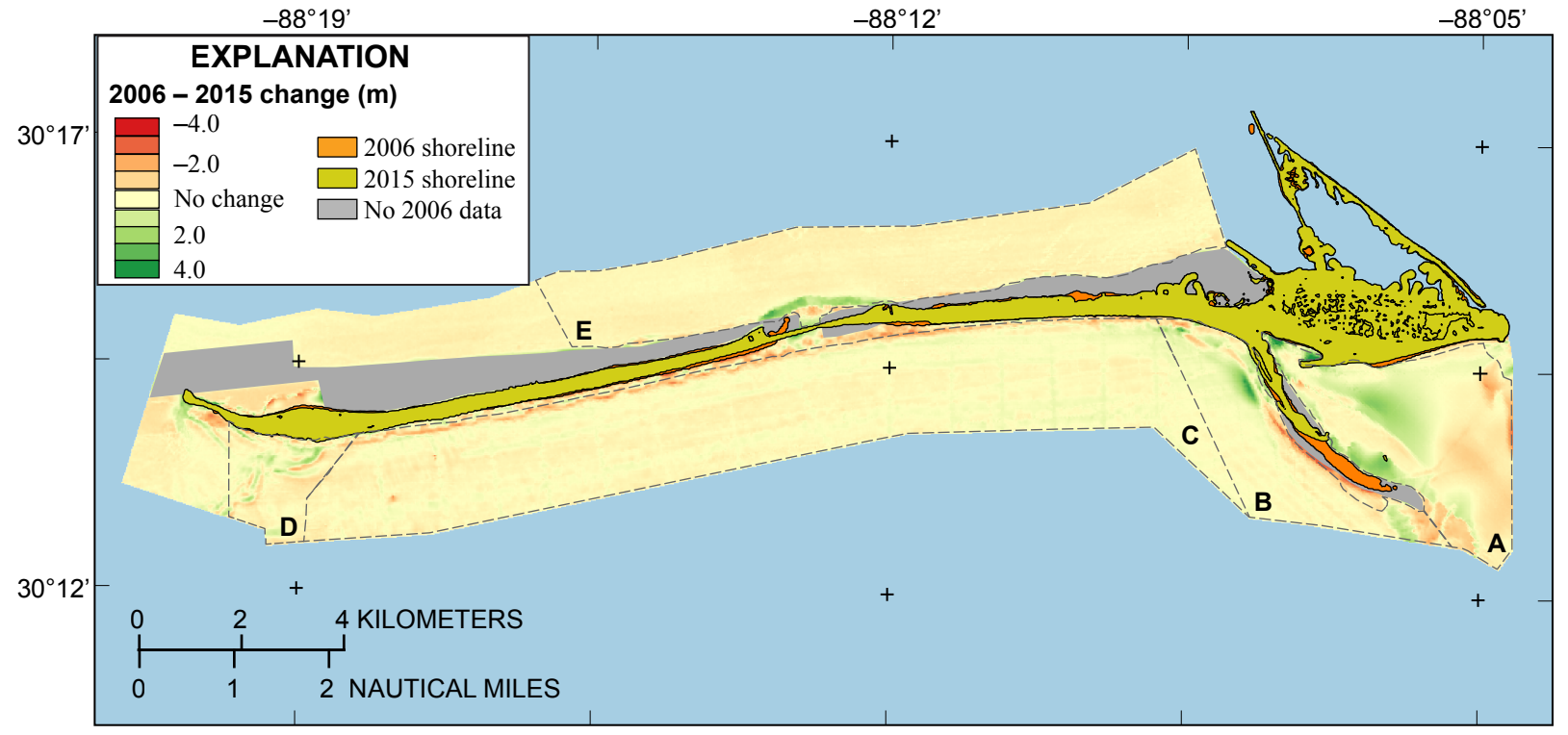

Figure 11. Map showing 9-year elevation change determined by calculating the difference in digital elevation models (DEMs) between 2006 and 2015, referred to as the non-stormy period. The change is considered to represent accretion (positive change) and erosion (negative change) over the time period. Elevation differences within $\pm 0.25 \mathrm{~meter}(\mathrm{~m})$ are considered no change. Overlain onto the DEM are polygons (labeled A-E) that represent morphological cells from which volume change statistics are calculated (table 2).

island. For effective volumetric change comparisons, only areas that contain bathymetric coverage for all three time periods were considered. The areas encompassed by the polygons are referred to as reference subsections of their respective feature. 


\section{Results and Discussion}

Morphologic features seen in the three time periods and referenced in this study include the highly dynamic Mobile and Petit Bois Pass ebb-tidal deltas and Pelican Island. In contrast, the Gulf of Mexico and Mississippi Sound sides of Dauphin Island contain few morphologic features, with the gulf side seafloor sloping gently seaward and the sound side being relatively flat. Other features include the breach in the island and associated overwash deposits that are visible in the 2006 DEM (fig. 7). Storm breaching has occurred in the same general vicinity in the past (Byrnes and others, 2010), reflecting the vulnerability of narrow island width and low elevations to storm inundation.

The three time periods (1987-2015; 1987-2006; and 2006-2015) represent multi-decadal change, impact of Hurricanes Ivan/Katrina, and recovery following Hurricanes Ivan/Katrina, respectively, and will be discussed in the context of these periods and events. It should be noted that other significant storms impacted the island during the early (1987-2006) time period, such as Hurricane Danny (1997), and Hurricane Georges (1998); however, since 2006, there has been relatively few significant storm impacts to the island (table 1). Thus, the early (1987-2006) and late (2006-2015) timeframes can be considered "stormy" and "non-stormy", respectively. In the 20 years before 1987, only four tropical storms passed within $185 \mathrm{~km}(100 \mathrm{~nm})$ of Dauphin Island (one of which, Hurricane Frederic, passed directly over the island as a category 4 storm). Relative to this prior two-decade period of 4 storms, the 1987-2006 timeframe (12 storms in two decades) can be considered exceptionally stormy.

The five areas of analysis (reference subsections A-E), where all three time periods contain seafloor measurements, are shown as polygons for each time period in figures 9-11. From these subsections sediment volumes were calculated and compared to assess volumetric change over time (table 2). Finally, six two-dimensional shore-perpendicular transects at various locations are compared over the three time periods to evaluate vertical change (locations shown in figs. 3, 7, and 8). The profiles will be discussed following the results of the volumetric change assessment.

\section{Long-Term Change (1987-2015)}

Over the three decades from 1987 to the present, barrier island retreat and breaching is evident in the long-term (1987-2015) comparison, as well as the occurrence of the breach in the middle of the island (fig. 9). In general, seafloor elevations around Dauphin Island have declined, with only the Mobile Bay and Petit Bois ebb-tidal delta regions producing net accretions of sediment (table 2). Mobile Bay ebb-tidal delta experienced only a slight net accretion. Sediment volumes increased 2 percent within the reference subsection (A) at a rate of $3.7 \times 10^{3} \mathrm{~m}^{3} / \mathrm{yr}$. This rate is relatively negligible when compared to change rates in other areas, suggesting the Mobile ebb-tidal delta cell is in equilibrium. Sediment transported westward to Pelican Island and beyond is replaced by sediment migrating from the eastern lobe of the Mobile ebb-tidal delta, which is separated from the western lobe by the Mobile Outer Bar ship channel. The ebb-tidal delta retains equilibrium despite large volumes of sediment being dredged from the ship channel and removed offshore. Byrnes and others (2008) estimate that between 1990 and $2006,10.8 \times 10^{6} \mathrm{~m}^{3}$ of sediment had been removed from the ship channel. Some of the historical offshore disposal areas are immediately offshore of the ebb-tidal delta and appear to be supplying sediment back to the western side of the Mobile ebb-tidal delta system (Byrnes and others, 2008).

The gulf-facing shoreface of Pelican Island has experienced the most change in elevation over the long-term time period as the island rapidly migrated landward and appended to Dauphin Island (fig. 9). The reference subsection (B) has lost 49 percent in sediment volume (table 2) as sediment moved out of the zone through shoreface erosion and sediment transport, both along the shoreline of Dauphin Island 
Table 2. Accretion and erosion volumes, net change, and rates of change for reference subsections of morphological features/areas of submerged areas around Dauphin Island. (Areas are shown for each time period as lettered polygons in figures 9-11.)

[ $\mathrm{m}^{3}$ cubic meter; $\mathrm{m}^{3} / \mathrm{yr}$, cubic meter per year; GOM, Gulf of Mexico; MS, Mississippi Sound; ETD, ebb-tidal delta]

\begin{tabular}{|c|c|c|c|c|c|c|}
\hline Time period & $\begin{array}{c}\text { Interval } \\
\text { years }\end{array}$ & Feature/area & $\begin{array}{c}\text { Accretion } \\
\left(10^{5} \mathrm{~m}^{3}\right)\end{array}$ & $\begin{array}{l}\text { Erosion } \\
\left(10^{5} \mathrm{~m}^{3}\right)\end{array}$ & $\begin{array}{l}\text { Change } \\
\left(10^{3} \mathrm{~m}^{3}\right)\end{array}$ & $\begin{array}{c}\text { Rate of change } \\
\left(10^{3} \mathrm{~m}^{3} / \mathrm{yr}\right)\end{array}$ \\
\hline \multirow[t]{5}{*}{$1987-2015$} & \multirow[t]{5}{*}{28} & Mobile ETD (A) & 50.10 & -49.06 & 103 & 3.69 \\
\hline & & Pelican Is. (B) & 21.53 & -44.19 & $-2,266$ & -80.92 \\
\hline & & Dauphin GOM (C) & 2.06 & -150.53 & $-14,847$ & -530.24 \\
\hline & & Petit Bois (D) & 18.08 & -10.16 & 791 & 28.26 \\
\hline & & Dauphin MS (E) & 5.32 & -115.64 & $-11,031$ & -393.97 \\
\hline \multirow[t]{5}{*}{ 1987-2006 } & \multirow[t]{5}{*}{19} & Mobile ETD (A) & 20.05 & -23.49 & -344 & -18.11 \\
\hline & & Pelican Is. (B) & 14.00 & -38.73 & $-2,473$ & -130.17 \\
\hline & & Dauphin GOM (C) & 0.77 & -99.31 & $-9,854$ & -518.62 \\
\hline & & Petit Bois (D) & 18.40 & -6.78 & 1,162 & 61.15 \\
\hline & & Dauphin MS (E) & 4.92 & -71.13 & $-6,621$ & -348.47 \\
\hline \multirow[t]{5}{*}{ 2006-2015 } & \multirow[t]{5}{*}{9} & Mobile ETD (A) & 37.20 & -28.69 & 851 & 94.56 \\
\hline & & Pelican Is. (B) & 14.41 & -11.25 & 315 & 35.05 \\
\hline & & Dauphin GOM (C) & 3.92 & -31.32 & $-2,740$ & -304.45 \\
\hline & & Petit Bois (D) & 4.53 & -7.40 & -287 & -31.86 \\
\hline & & Dauphin MS (E) & 8.15 & -31.15 & $-2,300$ & -255.55 \\
\hline
\end{tabular}

and rollover into the Mobile ebb-tidal delta. As a result, it has experienced the largest loss in volume per unit area $(-0.38 \mathrm{~m})$ of any of the cells. The adjacent Dauphin Island cell (C) received sediment transported from Pelican Island, resulting in accretion over the long term on the east edge of the cell (fig. 9). This positive budget is offset by shoreface erosion that increases westward as the long, narrow portion of the island migrated landward from $77 \mathrm{~m}$ on the east end to $164 \mathrm{~m}$ on the west end between 1987 and 2015. At the position of the 1987 shoreline, 3-4 m of vertical elevation has been lost. The gulf-facing shoreline reference subsection (C) lost about $530 \times 10^{3} \mathrm{~m}^{3} / \mathrm{yr}$ (table 2), the highest rate of any cell. Most of this loss occurred along the immediate shoreline, but erosion also occurred offshore across the western half of the island (fig. 9). Much of the sediment eroded from the gulf shoreface of Dauphin Island was transported through littoral transport westward to the island's terminal spit and Petit Bois Pass ebb-tidal delta, which is reflected both by the extension of the island and accretion offshore (fig. 9). From 1987-2015, the volume in the Petit Bois Pass reference subsection (D) increased by 79 percent, or $+28.3 \times 10^{3} \mathrm{~m}^{3} / \mathrm{yr}$, building shoreface shoals up to $5 \mathrm{~m}$ high. This influx of sediment has greatly expanded the Petit Bois Pass ebb-tidal delta over the past century through tidal-driven sediment accretion (Flocks and others, 2015).

In Mississippi Sound, the only appreciable gain of sediment in the reference subsection (E) occurred at the breach through storm overwash (fig. 9). This excludes deposition at the immediate shoreline through island migration because the reference subsection, in general, begins $200 \mathrm{~m}$ offshore (figs. 9-11; no 2006 data available at the shoreline). The rest of the area (E) uniformly lost 0.4 to $1.0 \mathrm{~m}$ in elevation at a rate of $-394 \times 10^{3} \mathrm{~m}^{3} / \mathrm{yr}$. There appears to be some shoreface erosion and subsequent deposition further into the sound, which will be explored further by comparing elevation profiles later in this discussion. 


\section{Stormy Period Change (1987-2006)}

During the 19-year time period ending in 2006, Dauphin Island was impacted by 12 storms, 4 of which had significant impact on the island (table 1), including the breach. Although the Mobile Bay ebbtidal delta experienced net accretion over the long term, during this time period a net loss of sediment occurred. Over twice as much sediment was removed from the reference subsection (A) during this time period than was gained long-term (table 2$)$, but at a relatively low rate $\left(-18 \times 10^{3} \mathrm{~m}^{3} / \mathrm{yr}\right)$ when compared to other areas around the island. Although removal of sediment from the system during storm impact is a large driver of the loss, approximately $7.0 \times 10^{5} \mathrm{~m}^{3} / \mathrm{yr}$ of sediment was dredged from the Mobile ship channel during this time period and placed in offshore sites (Byrnes and others, 2010), likely reducing the net sediment available to migrate westward into the study area. Accretion of sediment on the western flank of the Mobile cell occurred during rollover of Pelican Island (fig. 10), noting that coverage of this change is likely incomplete given that some of this area was not captured during the 2006 survey.

Between 1987 to 2006, Pelican Island has rotated counterclockwise so that the southern tip has migrated landward approximately $350 \mathrm{~m}$, and the northern tip has moved seaward about $60 \mathrm{~m}$. The island had also accreted approximately $650 \mathrm{~m}$ towards Dauphin Island (fig. 10) at the expense of the southern end. This movement has resulted in up to $3.8 \mathrm{~m}$ vertical loss in the southern portion of the Pelican Island reference subsection (B) and up to $3 \mathrm{~m}$ vertical gain adjacent to Dauphin Island. Net change in the Pelican Island reference subsection over this time period has been a loss of $2.5 \times 10^{6} \mathrm{~m}^{3}$, or $-130 \times 10^{3} \mathrm{~m}^{3} / \mathrm{yr}$ (table 2), as sediment has been removed from the system both through littoral transport and storm impact. Westward, along Dauphin Island, the most dramatic change was the formation of the breach, while the rest of the island experienced $1-3.25-\mathrm{m}$ elevation loss at the shoreface through erosion and landward migration (50 m east end to $95 \mathrm{~m}$ west end). The rate of loss $\left(5.2 \times 10^{5} \mathrm{~m}^{3} / \mathrm{yr}\right)$ within the reference subsection (C) over this time period is the highest of any time period in any subsection, and is a result of littoral transport westward and wave erosion during storms. In contrast, the Petit Bois Pass ebb-tidal delta reference subsection (D) experienced a sizable gain of $6.1 \times 10^{4} \mathrm{~m}^{3} / \mathrm{yr}$ over this time period. The amount of accretion and rate of gain, although by far the largest of any cell during any time period (table 2), is only 12 percent of the rate of loss along the adjacent gulf-facing Dauphin shoreline, suggesting episodic storm processes dominated nonstorm littoral transport along the island shoreface.

The Mississippi Sound side of Dauphin Island maintained a very high net loss rate that is very consistent with the long-term loss rate (table 2). Vertical erosion is fairly uniform throughout the subsection, the highest elevation loss $(\sim 1 \mathrm{~m})$ occurs $1+\mathrm{km}$ from the breach (fig. 10). Since the 2006 bathymetric dataset does not capture the shoreface on the sound side, the elevation gain of only a portion of overwash deposit at the breach can be measured and ranges from +0.3 to +1.0 in elevation between 1987 and 2006.

\section{Non-stormy Period Change (2006-2015)}

Since 2006, only two tropical storms passed within $184 \mathrm{~km}$ of Dauphin Island (table 1), thus normal (for example, non-storm) littoral processes are expected to be the dominant mode of sediment transport over the past decade. The Mobile ebb-tidal delta reference subsection (A) experienced a large amount of accretion during this period and the highest rate of gain of any subsection over any time period. Deposition more than doubled what had been lost over the previous period (table 2). Most of the elevation gain occurred within the northwest part of the subsection and is likely a result of littoral sediment trapping due to the welding of Pelican Island to Dauphin Island (fig. 11). Some rollover of the southern end of Pelican Island, although reduced from the previous (stormy) time period, may also contribute to the sediment surplus. 
The Pelican island reference subsection (B), which had significant erosion in the stormy time period, reversed loss and experienced almost an equal amount of accretion at a rate of $+35.1 \times 10^{3} \mathrm{~m}^{3} / \mathrm{yr}$ (table 2). The submergence of the southern portion of Pelican Island (fig. 11) likely contributed to sediment deposition within the reference subsection, and storm-induced rollover into the Mobile ebb-tidal delta cell has been reduced. West of where Pelican and Dauphin Islands merged, the remainder of Dauphin Island continued to thin through shoreface erosion, up to $100 \mathrm{~m}$ on the western end. Offshore sandbars migrated landward and welded to the shoreface, reducing seafloor elevations by up to $2 \mathrm{~m}$ approximately $200 \mathrm{~m}$ offshore, and increasing elevations by $1 \mathrm{~m}$ at the shoreline. The storm breach at the center of the island was closed by rock during this time period (2011), and there is approximately $2 \mathrm{~m}$ of accretion seaward of the structure. As throughout all time periods, the gulf side of Dauphin Island continued to lose sediment, although at almost half the rate of the previous time period (table 2), reflecting reduced storm-related erosion processes acting on the system. Within the Petit Bois Pass ebb-tidal delta, linear areas of erosion adjacent to areas of deposition are consistent with westward shoal migration (fig. 11). The shoals are 100-500 $\mathrm{m}$ in length and up to $2 \mathrm{~m}$ in height (fig. 3). The terminal spit has accreted $680 \mathrm{~m}$ westward from its 2006 position and littoral transport has contributed up to $3.5 \mathrm{~m}$ in elevation along the shoreface at the westernmost tip. Although the Petit Bois Pass reference subsection (D) had accreted substantially in the previous time period, during this period the net change was negative, accumulating 25 percent less sediment than was deposited during the prior decade. This suggests that littoral transport of sediment from Dauphin Island to Petit Bois Pass during non-stormy conditions is substantially less than what is liberated and transported during stormy conditions, and not enough to maintain equilibrium at this location without episodic deposition.

Like the gulf side of Dauphin Island, the sound side experienced erosion in all periods of analysis, although substantially less loss occurred during the 2006-2015 period than during the prior period. Rate of erosion in the reference subsection (E), although negative, decreased 65 percent from the stormy period (table 2). Elevation loss across the sound side was generally a uniform $0.2-0.3 \mathrm{~m}$. Prior to the breach being closed in 2011, floodtide deposits through the former inlet increased elevations by $1 \mathrm{~m}$ above overwash elevations approximately 300-400 m north of the structure. This is the only area in this cell that shows net accretion (fig. 11). Much of the shoreface on the sound side was not surveyed in 2006, but elevation change analysis from an area at the western tip of the island that was covered suggests erosion occurred all the way to the shoreline.

\section{Elevation Profiles}

Six transects (figs. 3, 7, and 8) — four shore perpendicular and two shore parallel—were chosen to compare elevation change across the 1987, 2006, and 2015 time periods. Transect T1 (fig. 12) is shore perpendicular and extends across the eastern margin of the Petit Bois Pass ebb-tidal delta. Sand ridges are visible as peaks in the elevation profiles, and comparison of the profiles over time show the sand ridges growing and migrating landward (fig. 12, location A). Shoreface accretion between 1987 and 2006 is reflected by the seaward migration of the profile, but this elevation gain was lost by 2015 (fig. 12, location B). Offshore, a divergence in the profiles over time represents the growth and movement of the ebb-tidal delta (fig. 12, location C).

Transect T2 (fig. 13) extends from Mississippi Sound south across the breach in the island and into the Gulf of Mexico (see figs. 3, 7, and 8 for location). Persistent erosion is seen in the loss of elevation across both the sound and the gulf (fig. 13, locations A and B), along with shoreface retreat (fig. 13, location B). The offshore and shoreface appear to have stabilized between 2006 and 2015. The island breaching between 1987 and 2006 is clearly evident, as well as the rock structure addition in 2011 (fig. 13, location C). 


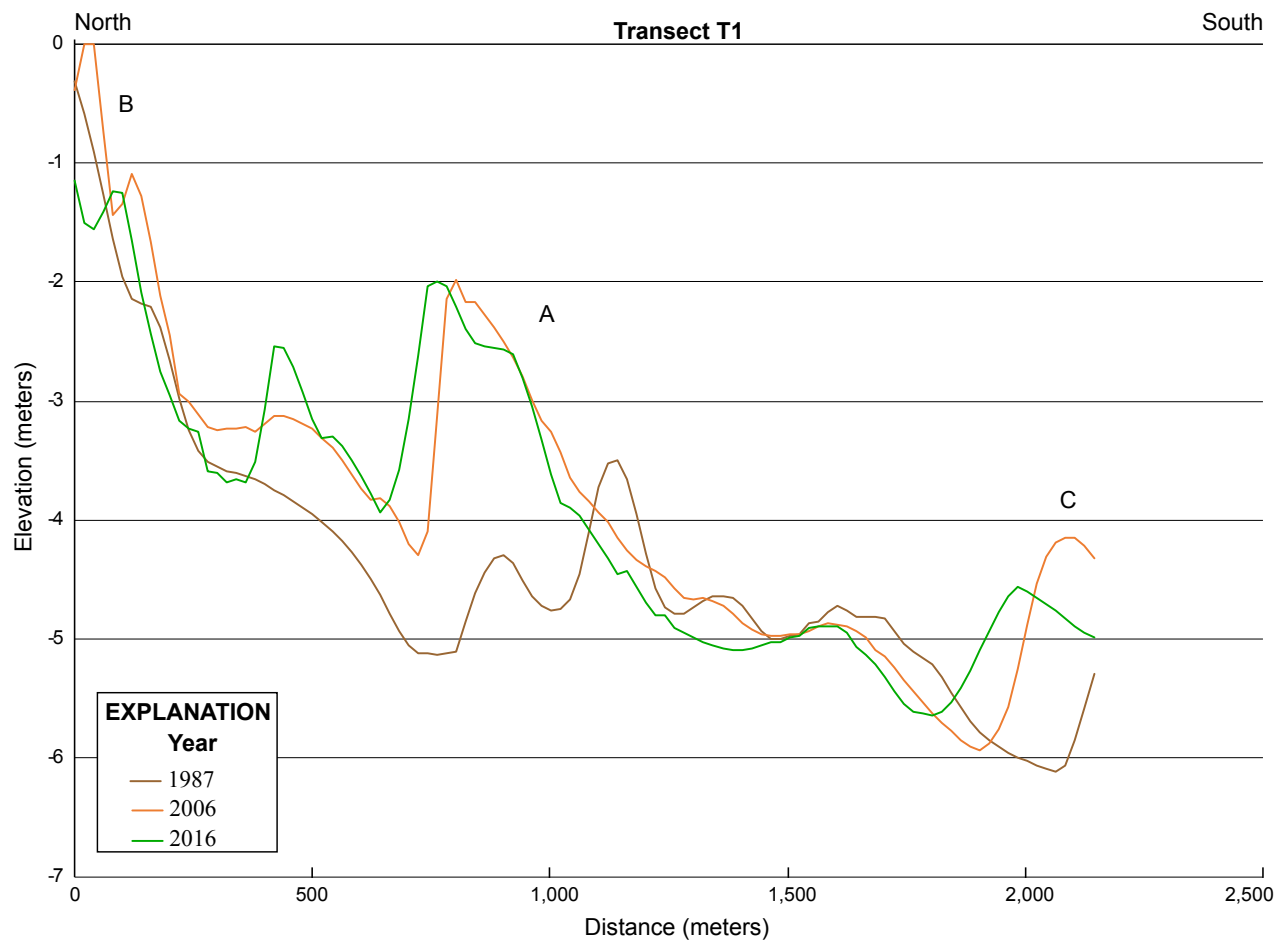

Figure 12. Elevation profiles across the Petit Bois ebb-tidal delta for the three time periods (transect T1, see figs. 3, 7, and 8 for locations). A, B, and $C$ refer to locations discussed in the text. The vertical exaggeration is 250x.

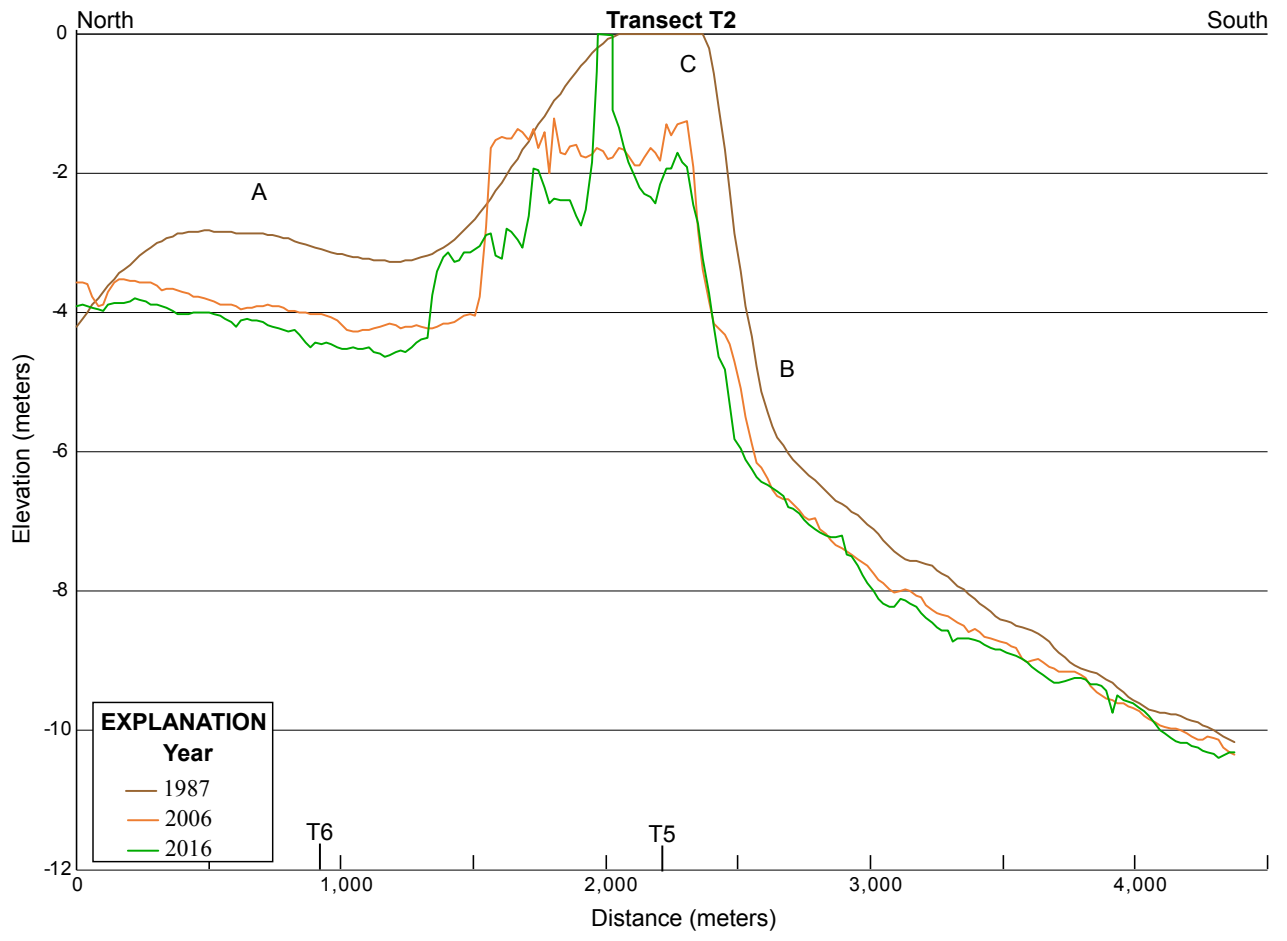

Figure 13. Elevation profiles from Mississippi Sound, across the island breach and into the Gulf of Mexico, for the three time periods (transect T2, see figs. 3, 7, and 8 for locations). Position of crossing transects (T5 and T6) are shown. A, B, and $\mathrm{C}$ refer to locations discussed in the text. The vertical exaggeration is $260 \mathrm{x}$. 
Transect T3 (fig. 14) extends seaward from the Pelican/Dauphin accretionary wedge offshore (see figs. 3, 7, and 8 for location). Sediment accretion as Pelican Island welded onto Dauphin Island is shown by up to a 3-m increase in elevation since 1987 (fig. 14, location A) and over $3 \mathrm{~m}$ accretion up to $1 \mathrm{~km}$ offshore. Beyond $1 \mathrm{~km}$, the seafloor has been stable throughout the time periods.

Transect T4 (fig. 15) is shore perpendicular across the Mobile Bay ebb-tidal delta (see figs. 3, 7, and 8 for location) and reflects the dynamic morphology of this deposit. At the Dauphin Island shoreline, shoreface retreat is evident by the landward migrating profiles and loss in elevation, between 1987 and 2015 (fig. 15, location A). Immediately offshore, up to $1 \mathrm{~m}$ of sediment has infilled a former tidal channel present in the 1987 profile (fig. 15, location B). Erosion along the transect has occurred from $1 \mathrm{~km}$ to $2.7 \mathrm{~km}$, with approximately 0.5 -m elevation loss occurring throughout (fig. 15, location C). At the seaward extent of the transect, along the edge of the ebb-tidal delta, landward shoal migration occurred between 1987 and 2006 as Pelican Island moved northward. Since 2006, the shoal has migrated landward of the transect and has been replaced by a small tidal inlet (fig. 15, location D).

Transect T5 (fig. 16) runs shore parallel along the gulf shoreline of Dauphin Island, from the Petit Bois Pass to Pelican Island (see figs. 3, 7, and 8 for locations). High-frequency nearshore sand waves are evident in all three time periods, some over $1 \mathrm{~m}$ in height (fig. 16, location A). A significant amount of erosion due to landward migration of the island is evident across four-fifths of the profile, as much as $4 \mathrm{~m}$ (fig. 16, location A). At the Petit Bois ebb-tidal delta, sand ridge development since 1987 has occurred, along with the infilling of a tidal channel (fig. 16, location B).

Transect T6 (fig. 17) is a shore-parallel profile across Mississippi Sound (see figs. 3, 7, and 8 for location). In general, the profile records the consistent loss in elevation across the sound since 1987—up to $1.5 \mathrm{~m}$ of loss - and the flanks appear to be more stable than the central portion of the profile (fig. 17). No sense of sediment-transport direction can be discerned from the profiles due to lack of data in the earlier datasets at the western end of Dauphin Island.

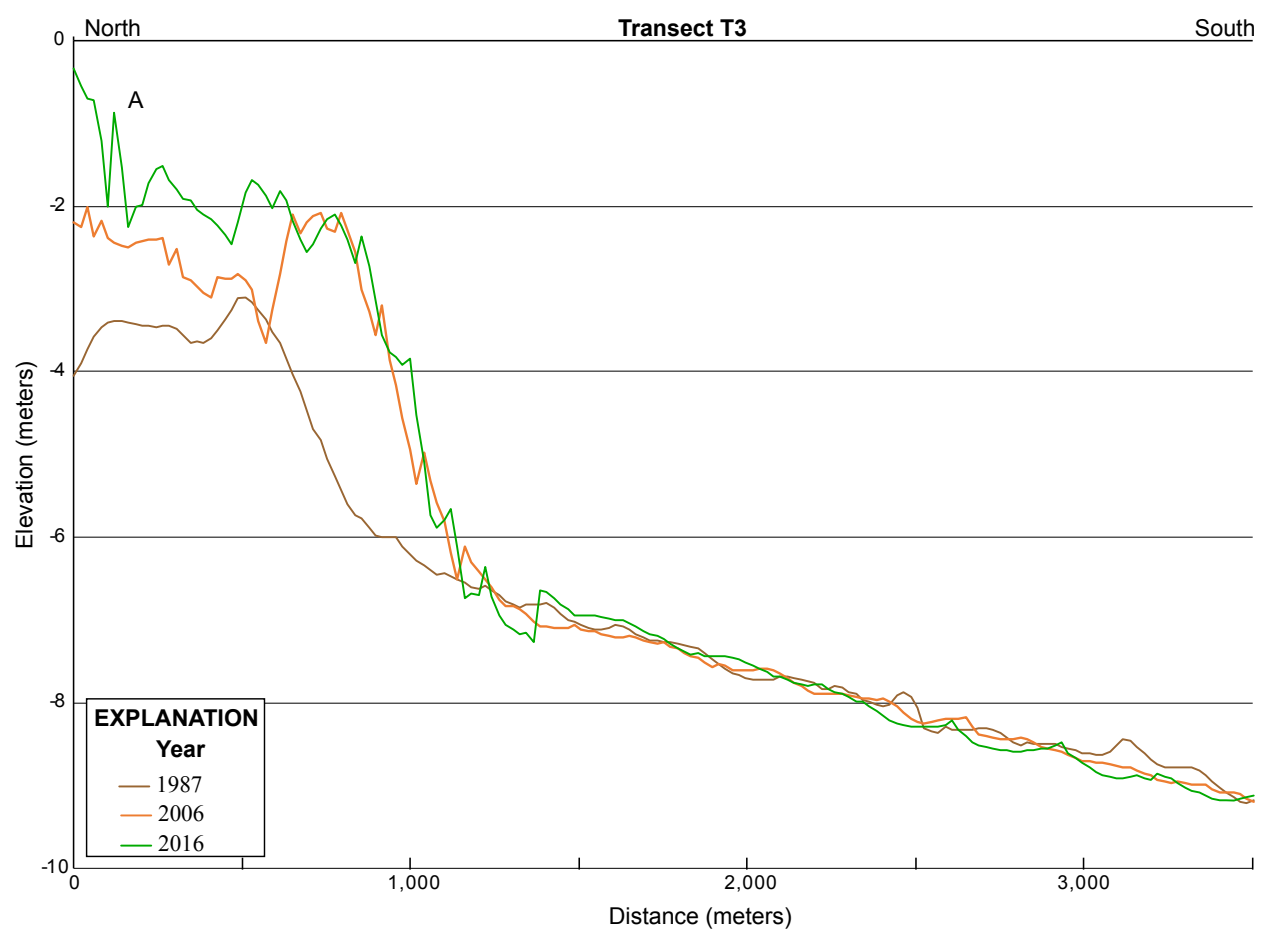

Figure 14. Elevation profiles along the gulf side of Pelican Island for the three time periods (transect T3, see figs. 3, 7 , and 8 for locations). A refers to a location discussed in the text. The vertical exaggeration is $240 x$. 


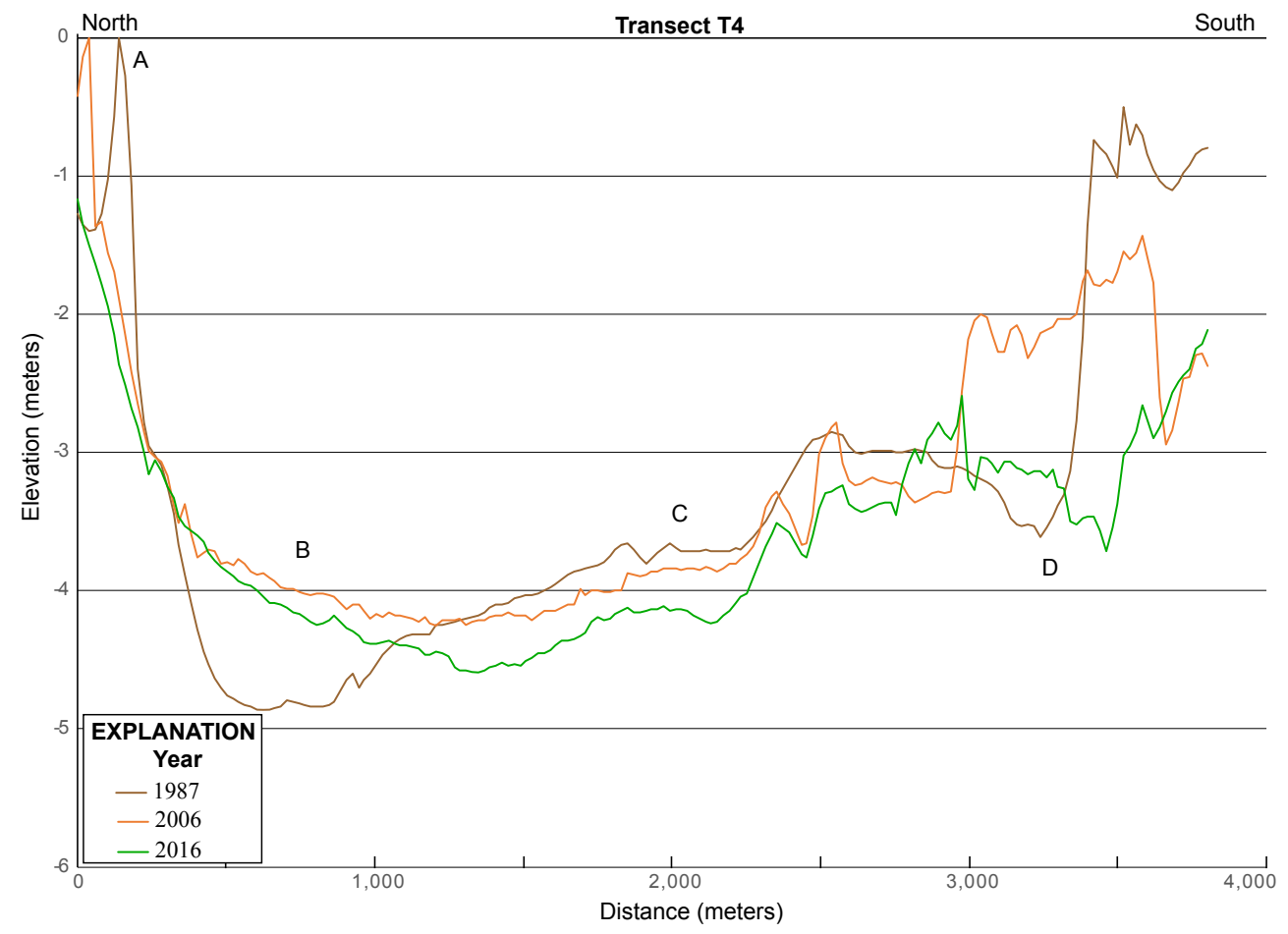

Figure 15. Elevation profiles across the Mobile ebb-tidal delta for the three time periods (transect T4, see figs. 3, 7, and 8 for locations). A, B, C, and D refer to locations discussed in the text. The vertical exaggeration is 460x.

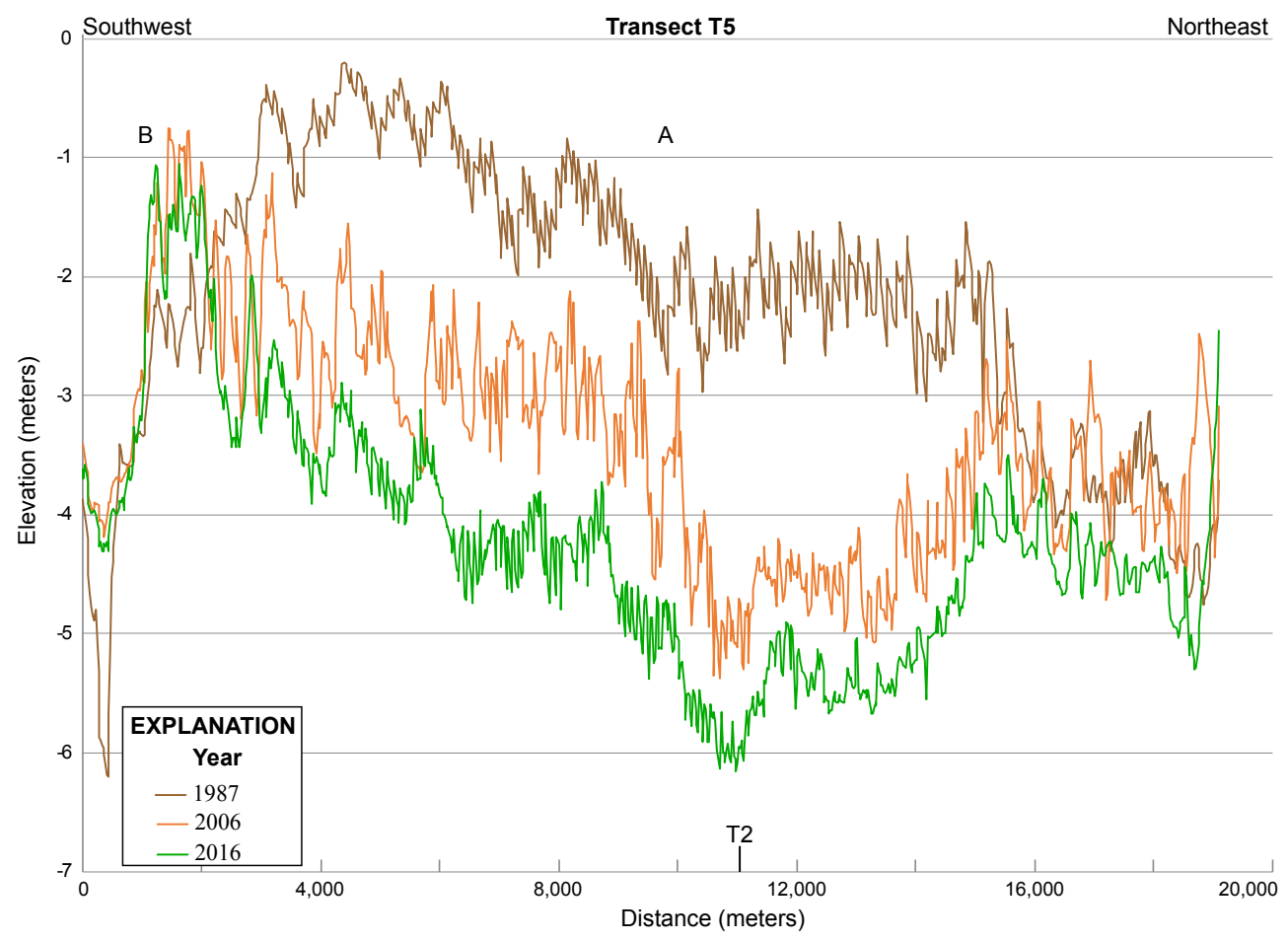

Figure 16. Elevation profiles across the gulf side of Dauphin Island for the three time periods (transect T5, see figs. 3, 7, and 8 for locations). Position of a crossing transect (T2) is shown. A and B refer to locations discussed in the text. The vertical exaggeration is 1980x. 


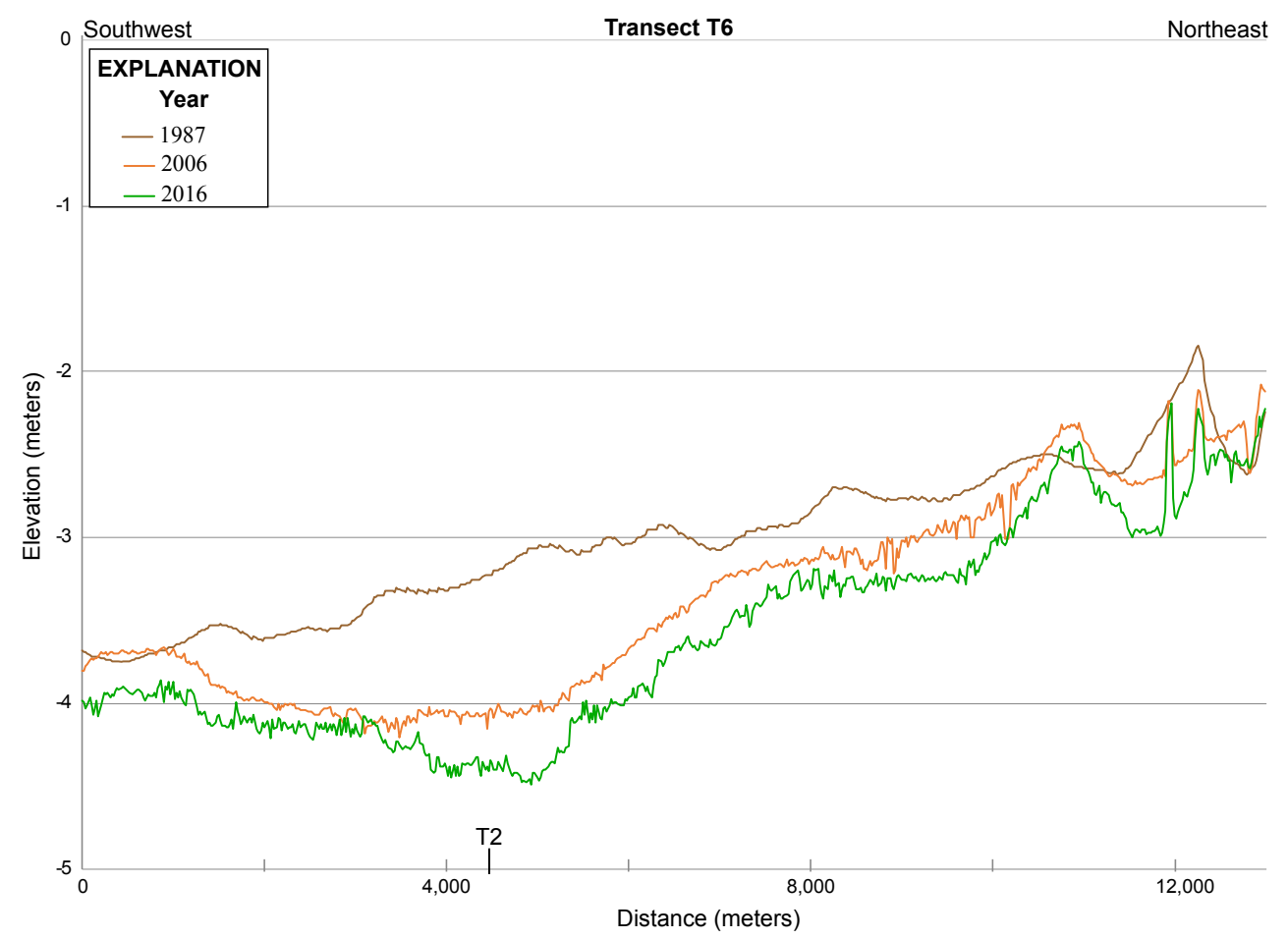

Figure 17. Elevation profiles across the sound side of Dauphin Island for the three time periods (transect T6, see figs. 3, 7, and 8 for locations). The vertical exaggeration is 1830x.

\section{Temporal and Spatial Sediment Flux}

Comparing changes in erosion rates over time (fig. 18), over the long term (1987-2015), the ebbtidal deltas were the only features to either remain in equilibrium (Mobile ebb-tidal delta, A) or accrete (Petit Bois Pass, D). The Gulf of Mexico (C) and Mississippi Sound (E) seafloor lost sediment at relatively high rates, and Pelican Island lost sediment at a relatively low rate. Since 1987, Pelican Island has been migrating landward and rolling over through overwash into the Mobile ebb-tidal delta, producing net loss within the reference subsection (B).

During the stormy period (1987-2006), only the Petit Bois Pass reference subsection (D) experienced a positive sedimentation rate, while all other areas experienced erosion. Loss at the Mobile ebb-tidal delta (A) was relatively small and could be in part due to dredging of the Mobile Outer Bar ship channel and removal of sediment offshore. During the non-stormy period (2006-2015), the gulf (C) and sound (E) sides of Dauphin Island continued to experience overall erosion of the shoreface, at rates 41 percent and 27 percent less, respectively, than during the stormy period (fig. 18). The ebb-tidal deltas flipped their response relative to the earlier period, with the Mobile ebb-tidal delta (A) gaining sediment at a rate higher than its prior loss, and Petit Bois Pass (D) losing sediment at a relatively small rate. The Pelican Island reference subsection (B) response flipped as well, gaining sediment during the nonstormy period. In addition, Pelican Island migrated toward and welded to Dauphin Island. The southern end submerged below water level, releasing sediment to the system. This change, and the reduction in significant storm-wave events that remove sediment from the system or cause the shoal to rollover, could explain the net gain to the Pelican Island cell. By welding onto Dauphin Island, Pelican Island trapped sediment within the Mobile ebb-tidal delta cell, resulting in accretion in the western part of the system during this time period (fig. 11). 


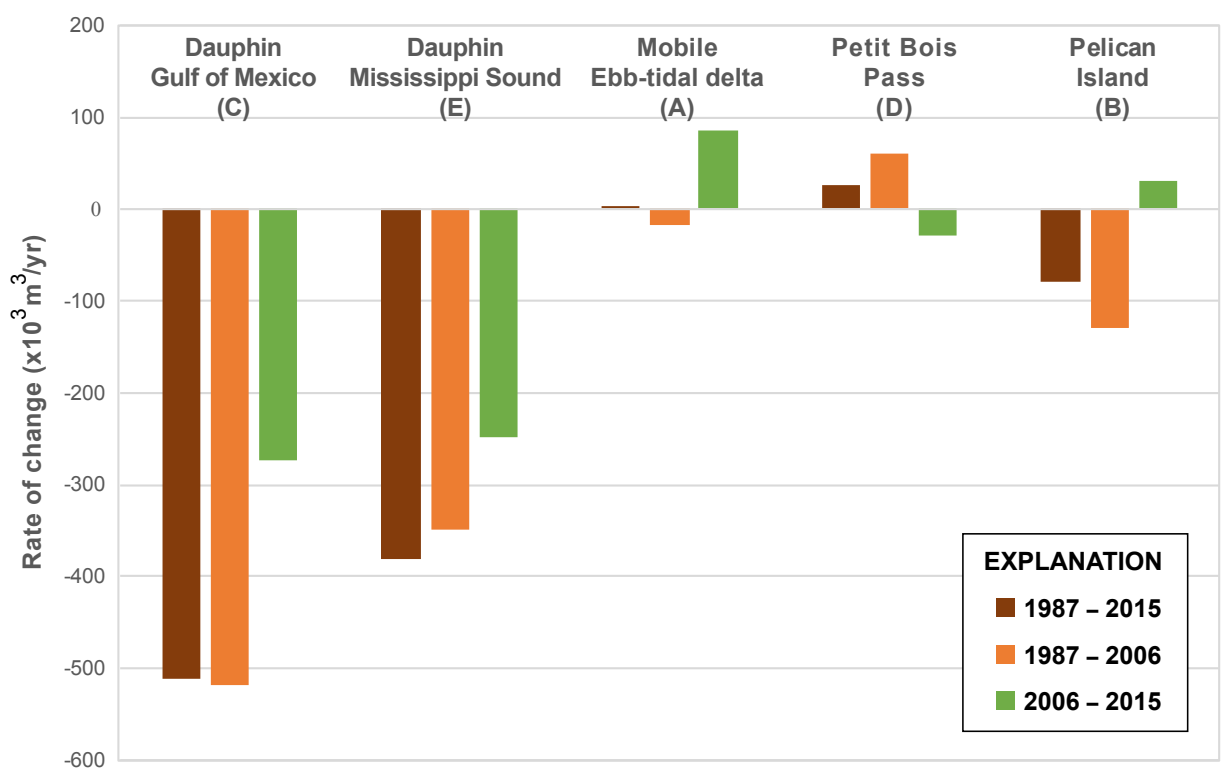

Figure 18. Rates of change (erosion/accretion over time) for the two time periods and long-term (1987-2015) for each reference subsection. See figures $9-11$ for locations.

\section{Conclusion}

The seafloor around Dauphin Island is spatially and temporally dynamic, with specific areas changing elevation at different rates in response to morphology and oceanographic conditions. In general, the submerged environment can be divided into the following five geomorphologic features: two ebb-tidal deltas (Mobile Pass and Petit Bois Pass) at the inlets on either end of Dauphin Island, Pelican Island/shoal on the western flank of the Mobile ebb-tidal delta, the shoreface of Dauphin Island facing the Gulf of Mexico, and the shoreface of Dauphin Island facing Mississippi Sound. Bathymetric change within these areas was analyzed over two time periods (1987-2006 and 2006-2015) and compared to the long term (1987-2015). The first time interval (1987-2006) corresponds to a period of frequent and intense storm impacts with 12 tropical storms passing near the island, 4 of them severe (table 1). During this time, episodic erosion and rapid transport of the seafloor sediments is expected to be the dominant process affecting elevation. In contrast, only two tropical storms passed by Dauphin Island during the second time interval (2006-2015). During this period, normal east-to-west littoral sediment transport, driven by a prevailing southeast wave climate, is the main process of seafloor change.

The geomorphologic features identified in the study do respond differently over the stormy and non-stormy time periods, which can be quantified through variations in erosion and accretion rates (fig. 18). By far the most erosion, both in volume and persistence, occurs along the central and western shoreface of Dauphin Island, both on the gulf and sound sides, with reduced net erosion occurring during the nonstorm period. The ebb-tidal deltas at either end appear to be in equilibrium relative to the rest of the island. The Mobile Pass ebb-tidal delta (A) appears to be "recovering" from Hurricanes Ivan/ Katrina through a net accumulation of sediment since 2006. Some of this accretion can be attributed to the welding of Pelican Island onto Dauphin Island and trapping sediment within the ebb-tidal delta that would otherwise migrate along the shoreface of Dauphin Island though a prevailing westward sediment transport. This prevailing transport supplies sediment to the Petit Bois Pass ebb-tidal delta from the Dauphin Island shoreface. Based on rates and volumes of erosion and accretion at the island shoreface 
and at Petit Bois Pass, westward sediment transport appears to be more significant during storm activity than during normal littoral transport. Petit Bois Pass experienced net accretion during the stormy period and net erosion during the non-stormy period, correlating with higher erosion rates at the Dauphin Island shoreface during the stormy versus non-stormy period (fig. 18). This suggests that sediment delivery during normal littoral transport, while occurring, does not maintain (or barely maintains) equilibrium at the Petit Bois Pass. The sound side of Dauphin Island mimics the trend of the gulf side and appears to also be supplying sediment to the Petit Bois Pass ebb-tidal delta through similar processes.

\section{References Cited}

Byrnes, M.R., Griffee, S.F., and Osler, M., 2008, Evaluation of channel dredging on shoreline response at and adjacent to Mobile Pass, Alabama: Report prepared for the U.S. Army Corps of Engineers, Mobile District, 199 p., accessed March 17, 2017, at http://www.sam.usace.army.mil/Portals/46/docs/planning _ environmental/acf/docs/072108-A-AQ963-014.pdf.

Byrnes, M.R., Griffee, S.F., and Osler, M., 2010, Channel dredging and geomorphic response at and adjacent to Mobile Pass, Alabama: Report prepared for the U.S. Army Corps of Engineers, Mobile District, ERDC/CHL TR-10-8, 311 p.

DeWitt, N.T., Stalk, C.A., Flocks, J.G., Bernier, J.C., Kelso, K.W., Fredericks, J.J., and Tuten, T., 2017, Single-beam bathymetry data collected in 2015 nearshore Dauphin Island, Alabama: U.S. Geological Survey data release, accessed May 30, 2017, at https://doi.org/10.5066/F7BZ648W.

Flocks, J.G., Ferina, N.F., and Kindinger, J., 2011, Recent geologic framework and geomorphology of the Mississippi-Alabama shelf, northern Gulf of Mexico, in Buster, N., Holmes, C., eds., Gulf of Mexico; Origins, waters and biota, 3. Geology; Texas A\&M University Press, College Station, Tex., p. 475.

Flocks, J.G., Kindinger, J.L., and Kelso, K.W., 2015, Geologic control on the evolution of the inner shelf morphology offshore of the Mississippi barrier islands, northern Gulf of Mexico, USA: Continental Shelf Research, v. 101, p. 59-70.

Guy, K.K., 2015, Barrier island shorelines extracted from Landsat imagery: U.S. Geological Survey OpenFile Report 2015-1179, 3 p., accessed March 17, 2017, at https://doi.org/10.3133/ofr20151179.

Otvos, E.G., and Giardino, M.P., 2004, Interlinked barrier chain and delta lobe development, northern Gulf of Mexico: Sedimentary Geology, v. 169, p. 47-73.

Parker, S.J., Davies, D.J., and Smith, W.E., 1997, Geological, economic, and environmental characterization of selected near-term leasable offshore sand deposits and competing onshore sources for beach nourishment: Geological Survey of Alabama Circular 190, 173 p. 


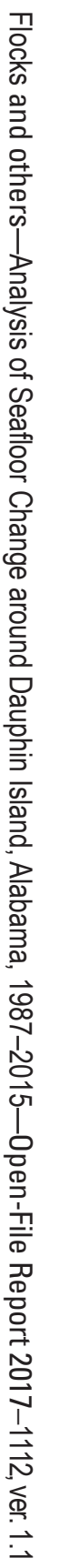

